REVIEW ARTICLE

Native bamboos with invasive traits: impacts, consequences and challenges with special emphasis on Asia Pacific region

S. Madawala* and T. Wijewickrama

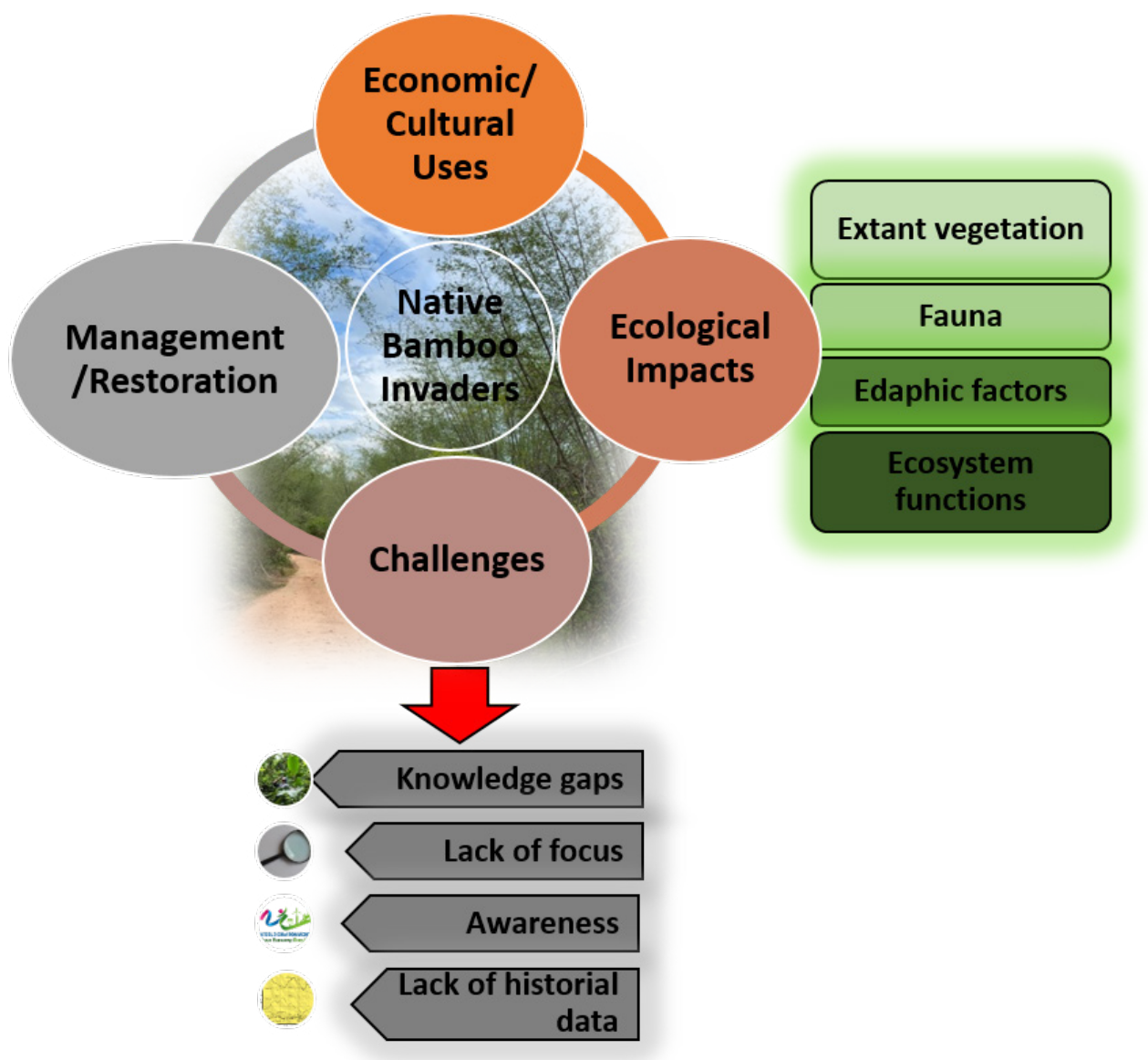

Highlights

- Invasive behaviour of 'native' species has often been overlooked until recently.

- Native invaders escape due attention owing to their many commercial uses.

- Some bamboo species expand their territories in native ranges in a rather ad hoc manner.

- Poor knowledge on 'native invaders' constraints feasible solutions for their control.

- This review highlights potential impacts, knowledge gaps and challenges. 
REVIEW ARTICLE

\title{
Native bamboos with invasive traits: impacts, consequences and challenges with special emphasis on Asia Pacific Region
}

\author{
S. Madawala ${ }^{1, *}$ and T. Wijewickrama ${ }^{2}$ \\ ${ }^{1}$ Department of Botany, Faculty of Science, University of Peradeniya, Peradeniya, Sri Lanka. \\ ${ }^{2}$ Postgraduate Institute of Science, University of Peradeniya, Peradeniya, Sri Lanka.
}

Received: 31/05/2021; Accepted: 30/09/2021

\begin{abstract}
Defying all norms of biological invasions, some native species expand their populations similar to their exotic counterparts causing potentially harmful impacts in native habitats. Despite an early caution by ecologists, they are now recognized as 'native invaders'. Though 'native' invaders may also incur harmful impacts similar to their 'exotic' counterparts, there are clear contrasts between them, thus demanding further studies to explore their life traits and cues that trigger their invasive traits. Among native invaders, bamboos are in the forefront due to their robust growth and resilience to harsh conditions. Also, it is a known fact that bamboo-dominated forests are on the increase globally while native forest are declining at a rapid rate. This review attempts to condense the current understanding of 'native' bamboos that spread in the Asia Pacific region with invasive potential and their short- and long-term ecological impacts. Possible environmental cues that may trigger their 'invasive' nature are also discussed. Of many, climate change seems to be the major driving force triggering their invasive behavior, though long-term studies are needed to ratify this link. Major challenges and knowledge gaps that hamper their control have also been deliberated. The evidence confirmed that native bamboos have the potential to incur negative impacts on ecology, social and economic aspects. However, their impacts are not always in parallel with that of 'exotic' invaders, thus cautioning any attempt of generalization. The lack of comprehensive research and historical information are considered as major impediments to identify suitable measures to manage them effectively. Further studies are mandatory to fill the existing knowledge gaps and to identify challenges to bring about effective management strategies to control 'native' bamboos with invasive potential.
\end{abstract}

Keywords: Bamboos; native invaders; ecological impacts; population expansions; native ranges; challenges.

\section{INTRODUCTION}

Until recently, studies have been carried out to recognize local, regional, and global driving forces accountable for the decline of native populations (Parmesan, 2006). Among other causes (i.e. land degradation, habitat loss, fragmentation and climate change), exotic invasive species are identified as one of the major contributors for the decline and extinction of native species (Harrison et al., 2006). Later, the ability of some native species to expand their territories similar to 'exotic' invaders has been emphasized. They expand populations into nearby natural and man-made habitats, sustaining potentially detrimental impacts (Campanello et al., 2007; Larpkern et al., 2011; Carey et al., 2012; Bai et al., 2013). However, the ability of native species to invade their home ranges and beyond did not receive the due recognition soon possibly due to the subtle nature of this emerging issue (Carey et al., 2012; Valéry et al., 2013). Garrott et al. (1993) rightly raised the importance of this evolving issue of 'native' invaders for the first time, with gaining momentum in research a decade later (Table 1). The baseline information on 'native' invaders could be crucial for policy makers to take tangible decisions in managing threatened habitats in an effective manner.

Among the known 'native' invaders, bamboos are in the forefront due to their exclusive life traits including fast growth, clonal reproduction, high phenotypic plasticity and competitive ability. It is reasonable to speculate that the sudden population expansion of bamboos may also incur similar or even harsher consequences to that of 'exotic' bamboo species. Thus, the present review attempt to critically analyze the recent literature on 'native' bamboos to describe ecological impacts following sudden population expansions. In addition to revisiting the available literature to evaluate impacts, the knowledge gaps and potential challenges were identified and discussed. The need for more focus on the 'invasive' behavior of native species under different habitat-climate settings to make informed predictions of their further expansion has also been highlighted (Carey et al., 2012; Dida et al., 2021).

Bamboos (Family: Poaceae) attract a global interest due to its uncommon life cycle, ecological significance, and a variety of commercial and cultural uses. Bamboos come from a single subfamily, Bambusoideae (Kigomo, 1988) which divides into three tribes, Olyreae (herbaceous), Bambuseae (tropical woody) and Arundinariaeae (temperate woody) (Ramanayake et al., 2007; Kelchner and BPG, 2013). Unlike other plant groups, the classification of bamboos sets challenges mainly due to paucity of reproductive structures. In 1988, Rao et al. noted 1,250 species of bamboo under 74 genera. Later on, 
Table 1: A list of literature published globally on native bamboo invaders during the past decade.

\begin{tabular}{|c|c|c|c|}
\hline Bamboo species & Focus of the study & Forest type/Country & Reference \\
\hline Guadua tagoara & Seedling community & Brazilian Atlantic Forest & Rother et al., 2018 \\
\hline Guadua tagoara & Seed rain and seed limitation & Brazilian Atlantic Forest & Rother et al., 2009 \\
\hline G. weberbaueri & Seed rain & Terra-firme forests in the Amazon, Brazil & Bona et al., 2020 \\
\hline Phyllostachys edulis & Soil microbial community & Subtropical forests in southern China & Tian et al., 2020 \\
\hline $\begin{array}{l}\text { Chusquea ramosissima } \\
\text { C. tenella }\end{array}$ & Impacts on tree saplings & Semi-deciduous Atlantic Forest, Argentina & Montii et al., 2013 \\
\hline Guadua sarcocarpa & Life traits and phenology of bamboo & Upland forests of the southwest Amazon & Carvalho et al., 2013 \\
\hline Phyllostachys pubescens & $\begin{array}{l}\text { Soil organic carbon and arbuscular } \\
\text { mycorrhizae }\end{array}$ & $\begin{array}{l}\text { Mixed coniferous and broadleaved forest in the } \\
\text { northern subtropics of China }\end{array}$ & Qin et al., 2017 \\
\hline $\begin{array}{l}\text { Guadua sarcocarpa } \\
\text { G. weberbaueri }\end{array}$ & $\begin{array}{l}\text { Management of bamboo-dominated } \\
\text { forests through logging }\end{array}$ & Southwestern Amazonia & Rockwell et al., 2014 \\
\hline Phyllostachys pubescens & $\begin{array}{l}\text { Net Primary Productivity and } \mathrm{N} \\
\text { cycling }\end{array}$ & $\begin{array}{l}\text { Evergreen broadleaved forest in subtropical } \\
\text { China }\end{array}$ & Song et al., 2017 \\
\hline Phyllostachys edulis & $\begin{array}{l}\text { Structure and diversity of soil } \\
\text { microbial community }\end{array}$ & $\begin{array}{l}\text { Subtropical monsoon forest in southeastern } \\
\text { China }\end{array}$ & Xu et al., 2015 \\
\hline Phyllostachys edulis & Soil $\mathrm{C}$ and $\mathrm{N}$ pools & A nature reserve in southeastern China & Bai et al., 2016a \\
\hline $\begin{array}{l}\text { Guadua sarcocarpa } \\
\text { G. weberbaueri }\end{array}$ & Physical damages on tree recruitment & $\begin{array}{l}\text { Terra firme tropical moist Amazonian forests in } \\
\text { south-eastern Peru }\end{array}$ & $\begin{array}{l}\text { Griscom and Ashton, } \\
2006\end{array}$ \\
\hline Guadua tagoara & Forest structure and dynamics & $\begin{array}{l}\text { Atlantic Forest of southern São Paulo State, } \\
\text { Brazil }\end{array}$ & Lima et al., 2012 \\
\hline Moso bamboo & $\begin{array}{l}\text { Human disturbances as a contributory } \\
\text { factor for invasion }\end{array}$ & Broadleaved forest in southern China & Bai et al., 2016b \\
\hline $\begin{array}{l}\text { Bambusa tulda } \\
\text { Cephalostachyum } \\
\text { pergracile }\end{array}$ & Tree regeneration & Tropical monsoon forest in Thailand & $\begin{array}{l}\text { Larpkern and Totland, } \\
2011\end{array}$ \\
\hline $\begin{array}{l}\text { Bambusa tulda } \\
\text { Cephalostachyum } \\
\text { pergracile }\end{array}$ & Tree regeneration & Mixed deciduous forest in northeastern Thailand & Larpkern et al., 2011 \\
\hline Phyllostachys edulis & Species diversity and dynamics & A nature reserve in China & Bai et al., 2013 \\
\hline Chusquea valdiviensis & Bird population & Temperate forest in southern Chile & Reid et al., 2004 \\
\hline Guadua sarcocarpa & $\begin{array}{l}\text { Fire as a factor contributing for } \\
\text { bamboo expansion }\end{array}$ & $\begin{array}{l}\text { Guadua-dominated forests of the south-west } \\
\text { Amazon }\end{array}$ & $\begin{array}{l}\text { Smith and Nelson, } \\
2011\end{array}$ \\
\hline Guadua tagoara & Avian assemblages & Brazilian Atlantic forest & Rother et al., 2013 \\
\hline Phyllostachys edulis & Soil biochemical properties & Japanese cedar (Cryptomeria japonica) forest & Shiau and Chiu, 2017 \\
\hline Sasa chartacea & Understory plant community & Plains in Japan & $\begin{array}{l}\text { Tomimatsu et al., } \\
2011\end{array}$ \\
\hline Guadua tagoara & $\begin{array}{l}\text { Phylogenetic structure of seeds and } \\
\text { seedling community }\end{array}$ & Old-growth Atlantic Forest & Schweizer et al., 2017 \\
\hline $\begin{array}{l}\text { Sasa palmata } \\
\text { S. kurilensis }\end{array}$ & Tree regeneration & Beech forest in Japan & Masaki et al., 2021 \\
\hline Phyllostachys heterocycla & Soil bacterial community structure & Broadleaved forest in southern China & Zhang et al., 2020 \\
\hline Woody bamboos & Tree density and basal area & Andean Forests & Fadrique et al., 2021 \\
\hline Guadua weberbaueri & Litter dynamics & Amazonian forest, Brazil & Dantas et al., 2020 \\
\hline Not specified & $\begin{array}{l}\text { Drought mediated fires as a factor for } \\
\text { expansion }\end{array}$ & Amazonian forest, Brazil & Da Silva et al., 2021 \\
\hline Aulonemia aristulata & Seed rain & Tropical temperate forest in southeastern Brazil & $\begin{array}{l}\text { Grombone-Guaratini } \\
\text { et al., } 2014\end{array}$ \\
\hline
\end{tabular}




\begin{tabular}{|c|c|c|c|}
\hline Phyllostachys edulis & $\begin{array}{l}\text { Precipitation as a factor for bamboo } \\
\text { distribution }\end{array}$ & China & Shi et al., 2020 \\
\hline Guadua spp. & Community structure of beetles & Terra firme forests in Peru & Jacobs et al., 2018 \\
\hline Bambusa bambos & Abundance and richness of AMF & Tropical Moist Evergreen Forests, Sri Lanka & Mafaziya et al., 2019 \\
\hline B. bambos & $\begin{array}{l}\text { Community perceptions on bamboo } \\
\text { spread }\end{array}$ & Tropical Moist Evergreen Forests, Sri Lanka & $\begin{array}{l}\text { Wijewickrama et al., } \\
2019\end{array}$ \\
\hline B. bambos & $\begin{array}{l}\text { Structure and composition of the } \\
\text { extant forest community }\end{array}$ & Tropical Moist Evergreen Forests, Sri Lanka & $\begin{array}{l}\text { Wijewickrama et al., } \\
2020\end{array}$ \\
\hline B. bambos & $\begin{array}{l}\text { Seedling recruitment, mortality and } \\
\text { regeneration potential }\end{array}$ & Tropical Moist Evergreen Forests, Sri Lanka & $\begin{array}{l}\text { Wijewickrama et al., } \\
2021 \text { (in press) }\end{array}$ \\
\hline B. bambos & Litter-dwelling arthropod community & Tropical Moist Evergreen Forests, Sri Lanka & $\begin{array}{l}\text { Wijewickrama et al., } \\
\text { (unpublished) }\end{array}$ \\
\hline
\end{tabular}
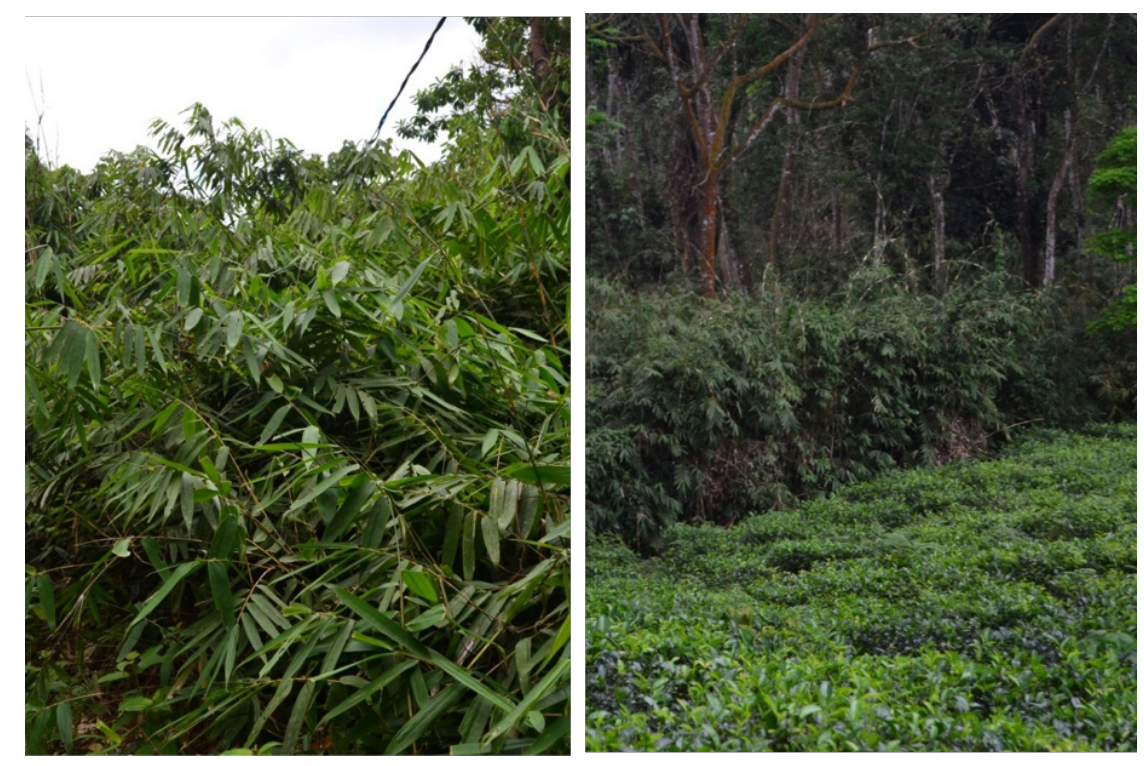

Figure 1: Ochlandra stridula, an endemic bamboo species in Sri Lanka and in the Western Ghats in India, showing a tendency to expand its populations in forests in the lowland wet zone of Sri Lanka. (C) Tharanga Wijewickrama.

1,662 species of bamboos were identified in 121 genera (Canavan et al., 2016), adding a significant number to the list. Based on molecular studies, the tribe Bambuseae was further divided into 11 subtribes; whereas Olyreae into 3 subtribes (Kelchner and BPG, 2013; Soreng et al., 2017). The subtribal classification of Bambuseae and Olyreae seems clearer than that of Arundinarieae (Zhang et al., 2021). The most recent literature observed nearly 1,700 bamboo species in 127 genera (Clark and Oliveira, 2018).

Over the years, bamboos are introduced intentionally outside their native ranges for numerous purposes, and over time some become invasive causing harmful impacts on biodiversity and ecosystem services (Fukushima et al., 2015; Umemura and Takenaka, 2015). Of all bamboo species, a few are categorized as 'exotic' invaders, of which the majority are 'running' bamboo species. The 'native' bamboos are considered as an important component in forest ecosystems, until a few turn into 'invasive' triggered by unknown environmental cues. Phyllostachys edulis (moso bamboos) and P. bambusoides in China and Japan (Yang et al., 2008; Bai et al., 2013; Xu et al., 2015), few species belonging to Chusquea and Guadua genera in Atlantic forests in the South America (Montii et al., 2011; Lima et al., 2012; Rother et al., 2016), Bambusa bambos in south-east Asia (Canavan et al., 2016; Jayawickrama et al., 2019, 2020) and Ochlandra stridula (an endemic) in Sri Lanka [(Prematilleke et al., 2014) (Figure 1)] are some known 'native' bamboo species with an invasive potential. Unfortunately, 'native invaders' evade attention from the conservationists due to the general assumption that all native species are harmless. Pivello et al. (2018) named 'native' invaders as 'super-dominant' natives and identified 16 such terrestrial species that need attention in Brazil, out of which 5 belonged to bamboos.

\section{Limits of the review}

Though both 'native' and 'exotic' bamboos are known for their 'invasive' behaviour (Bai et al., 2013), this review will focus only on 'native' bamboo species displaying 'invasive' potential. Despite receiving less attention on their adverse impacts, few studies have been carried out in the Asia-Pacific region exploring ecological impacts of native bamboo invaders, revealing a new vista for further research. Despite the growing interest on this emerging issue, the information on short- and long-term ecological impacts of native bamboos is still scanty and unambiguous. Thus, the main objective of this review is to examine the available scientific literature on 'invasive' native bamboo species and their potential impacts to shed light on the severity of this long-ignored issue, and to 
ascertain underlying causes for their unusual behavior. In order to impose a self-boundary, the review focuses mainly on related literature from the Asia-Pacific region. This review may also attempt to identify knowledge gaps that need further investigation, challenges that impair the policy makers, and finally to make recommendations to control further invasion and mitigate their potentially detrimental impacts.

\section{Invasion versus over-dominance}

Invasion of exotic/alien species and their impacts are welldocumented globally. Of many definitions of 'invasive species', the common fact is that the focal species should be an 'alien'/ 'exotic' or a 'non-native'. This is the major reason for discounting 'native' invaders by conservationists and scientists. With the steady growth of publications highlighting the enormity of this evolving problem, a new definition is introduced to overcome this disparity. In place of 'invasion', the terms 'over-abundance' (or 'overdominance') and 'expansion' have been proposed to evade unnecessary overlaps (Conlisk et al., 2013; Wijesundara, 2017), while Simberloff (2012) termed this special group of 'native' plants as 'native' invaders.

While impacts of 'exotic' invasive species are relatively well-explored under diverse climate and habitat conditions, the impacts of 'native' invaders are less known (Lima et al., 2012). It is quite justifiable to foresee that the impacts of 'native invaders' are more or less comparable to that of 'exotic' invaders. However, the dearth of studies on 'native invaders' make it difficult to contrast and generalize impacts under different habitat-climate settings. Thus, this review would pave the way to find likely similarities and/or dissimilarities between these two groups of plants and their so-called more or less similar circumstances, 'invasion' and 'expansion', with the available literature.

\section{Bamboo: it's current distribution}

Multiple economic uses together with intrinsic life traits give bamboos a distinctive place amongst other terrestrial plants. Bamboos are rapid-growing plants with unusual flowering patterns. Ghinkul (1936) classified bamboos into three groups based on their senescence behavior, though a majority are known to possess a single reproductive event in its life cycle which involves massive flowering followed by mass death [(Keeley and Bond, 1999), Figure 2].

Over 6.3 million $\mathrm{km}^{2}$ of bamboo forests are reported to exist from Northeastern India through Burma to Southern China, and also from Sumatra to Boneo (Bystriakova et al., 2003). Bamboos show the highest species richness in the Asia-Pacific region, followed by South America and Africa (Bystriakova et al., 2003). In the Asia-Pacific region, China has recorded the highest species richness (626 species), followed by India with 148 species (Sharma and Nirmala, 2015). The highest species richness per area (with 144 species per $\mathrm{km}^{2}$ ) is also recorded in forests in Southern China. In India, more than $50 \%$ of the naturally occurring bamboo species are known to be endemic. Bambusa, Dendrocalamus and Ochlandra are the three most dominant genera in India with each representing more than 10 species, which represent $45 \%$ of the total bamboo species in the country (Sharma and Nirmala, 2015). In the South American sub-continent, Brazil has the greatest bamboo diversity (137 species). The clump-forming bamboos are rich in the tropical belt (Uchimura, 1987), while the herbaceous bamboos are confined mainly in the Neotropics of Brazil, Paraguay, Mexico and West Indies (Yeasmin et al., 2015).

Despite bamboos growing naturally in all major continents except in Europe (with the ability to thrive from just above sea level to $4,000 \mathrm{~m}$ ), their distribution is known to be highly irregular (Behari, 2006; Goyal et al., 2012). Globally, woody bamboos are distributed in three major regions viz., paleotropical (tropical and subtropical regions of Africa, Madagascar, Sri Lanka, India, Southern Japan, Southern China and Oceania), neotropical (Southern Mexico, Argentina, Chile and West Indies), and North temperate (North Temperate Zone and at higher elevations of Madagascar, Africa, India and Sri Lanka). In the tropics

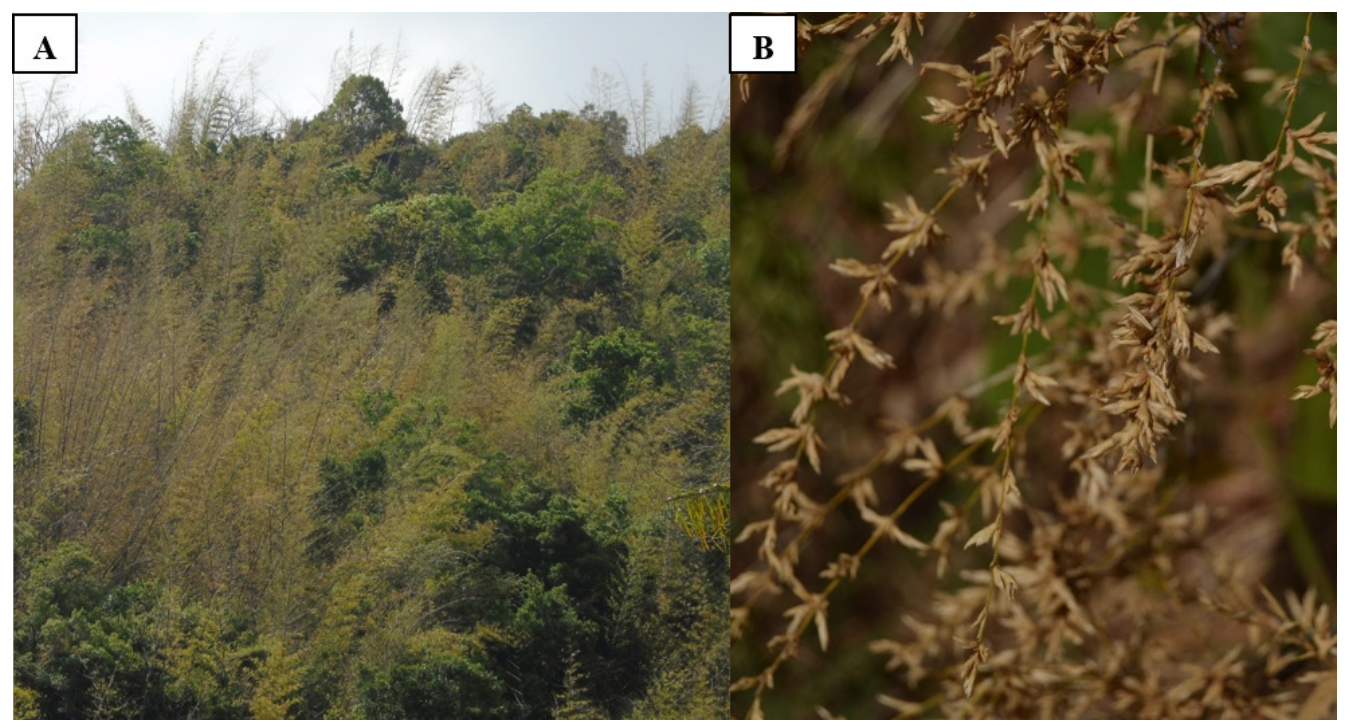

Figure 2: Bamboos play an important component in both wet and dry zone forests in Sri Lanka. A: the spread of native Bambusa bambos in moist evergreen forests in Sri Lanka altering the forest structure and composition; B: flowering of B. bambos. Location: Moragahakanda, Naula, Sri Lanka (C) Imesh Weerasinghe and Tharanga Wijewickrama. 
and sub-tropics, bamboos forests encompass a total extent of 22 million hectares (Zhou et al., 2005). While broadleaved forest cover is dwindling rapidly, the extent of bamboo forests has been gradually expanding over time (Zhou et al., 2005). China, in particular, has increased its bamboo forest cover steadily to an extent of 5 million $\mathrm{hm}^{2}$ as at 2000 (Xiao, 2000).

Though bamboo is considered as a major component in tropical forests, some countries, such as Sri Lanka, do not identify bamboo forests in its major forest classifications due to its rather localized distribution. According to Soderstrom and Ellis (1988), Sri Lanka has three subtribes of Bambuseae, which include six genera and 12 species. In the subtribe of Arundinariinae, there are five species of genus Arundinaria. The subtribe Bambusinae comprises three genera, Bambusa, Dendrocalamus and Pesudoxytenanthera, while the subtribe Schizostachydinae is represented by Ochlandra stridula and Davidsea attenuata.

\section{Uses of bamboo}

Bamboos provide many important ecosystem and economic services to their native and introduced ranges. In terms of ecological impacts, bamboos facilitate forest dynamics through distinct flowering events and die offs (Keeley and Bond, 1999). Bamboo plays a critical role in carbon storage, water and soil conservation, and even in mitigating impacts of climate change (Zhou et al., 2005; Song et al., 2015) (Figure 3). Bamboo forests tend to retain soil moisture through increased litter production and accumulation (Shinohara et al., 2015). High biomass production may also contribute positively to the rehabilitation of degraded lands. Bamboos are also use in agroforestry systems in China, India and Thailand ( $\mathrm{Fu}$ et al., 2000). Bamboo forests are known as efficient carbon sinks (Zhou and Jiang, 2004; Song et al., 2015), with exciting numbers to back their contribution in the climate change mitigation. In China, the carbon density in bamboo forests ranged from 168.7 to $259.1 \mathrm{t} \mathrm{C} \mathrm{ha}^{-1}$ which is much higher than that of many other forest types ( $\left.38.7 \mathrm{t} \mathrm{C} \mathrm{ha}^{-1}\right)$ as well as the global

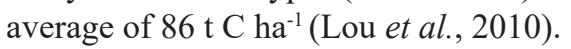

In addition, there are many known intriguing relationships of bamboos with animals indicating their long history in the evolutionary trajectory. Some animals prefer bamboo-dominated forests over other forest types (Rockwell et al., 2014), especially during mast fruiting episodes (Sieving et al., 2000), probably due to the bounteous availability of food. Reid et al. (2004) showed compelling evidence to suggest that some bird species prefer the undergrowth of bamboo-dominated forests over others without bamboo. However, Coggins (2000) categorized bamboo plantations in South-East of China as the least valuable habitats for wildlife, indicating speciesspecific preferences by animals.

In addition to crucial ecological services, bamboos have many other commercial, agricultural and cultural uses as well. Bamboos show a high potential as a commercial commodity due to their rapid growth with zero inputs. Thus, it is one of the most significant non-timber forest products (NTFP) in the Asia-Pacific region. Being termed as 'poor man's timber', the rural people opt bamboo as a raw material in construction, agriculture and farming activities for decades. However, the commercial value of bamboos has diminished gradually over the years, with a renewed interest in recent times. Bamboos are used for many diverse and innovative practices in cottage-based industries and in poverty alleviation programs. In India, thorny bamboo species have been explored as a potential alternative for electric fencing to ward off wild elephants from human settlements and tea plantations (Dutta, 2016). However, this has been disputed by a recent study carried out in Sri Lanka where local communities claimed an intensified presence of elephants since the expansion of thorny $B$. bambos perhaps due to high palatability of young bamboo shoots (Wijewickrama et al., 2019). However, in recent times, bamboo has been identified as a source of sustainable raw material to reduce the demand on other timber sources.

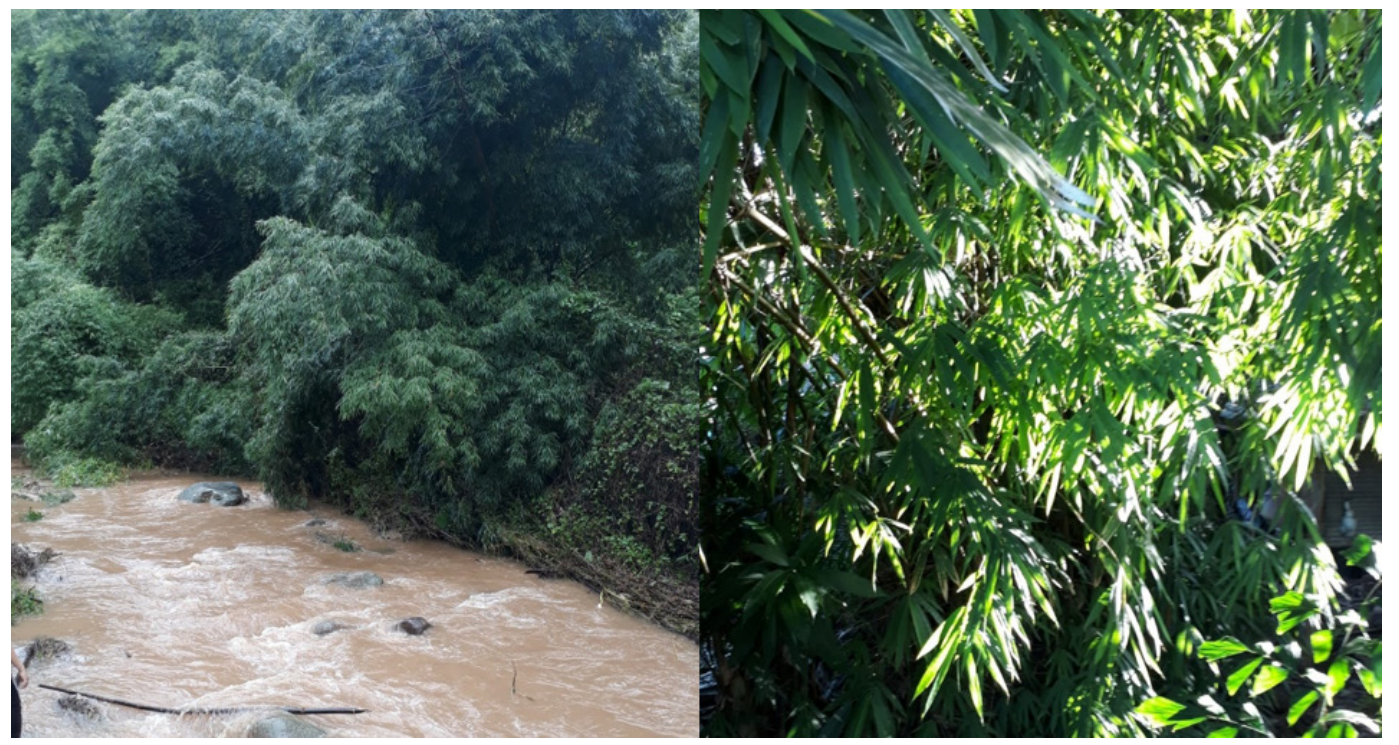

Figure 3: Dendrocalamus sp. are often discovered close to streams. Location: Doi Hang, Chiang Rai, Thailand. (C) Binu Samarakoon, Center of Excellence in Fungal Research, Mae Fah Luang University, Chiang Rai, Thailand. 

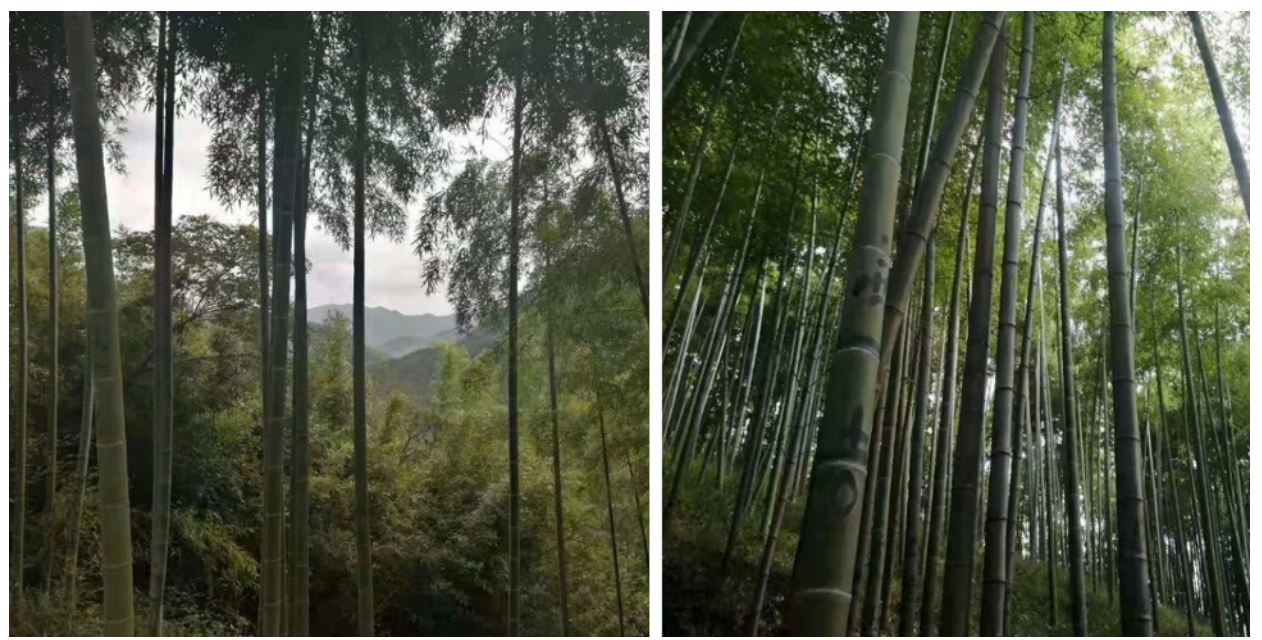

Figure 4: Moso bamboo (Phyllostachys sp.) groves at Moganshan, Hangzhou, Zhejiang Province, China. (C) Charlotte King, International Bamboo and Rattan Organization (INBAR).

\section{Invasive nature of bamboos}

Bamboos in general are less likely to invade habitats due to their rare flowering events and their preference for narrow range of environmental conditions to thrive. For a long time, conservationists were reluctant to recognize them as 'invasive' possibly owing to their known economic and cultural uses. As a result, they rarely appeared in 'potentialfor-expanded-distribution lists in country reports. As of 2016 , only 12 woody bamboo species $(0.7 \%)$ had been formally identified as 'invasive' (Canavan et al., 2016). Relatively more literature is available on invasiveness of exotic bamboo species and their impacts on biodiversity, ecosystem, and their services (Pagad, 2016). In contrary, the 'invasive' nature of native bamboo species received due attention much later.

While natural forest cover is in the decline world over, bamboo forests are expanding their territories in a rather unprecedented manner, especially during the last few decades. In China, the area under bamboo has increased by $14.5 \%$ during a span of 9 years since 2004 , which is nearly $10 \%$ higher compared to the previous decade (Xu et al., 2020). The area under the native moso bamboo has been extended markedly over the years [(Chang and Chiu, 2015; Bai et al., 2016), Figure 4]. In Japan, a massive increase (270\%) of bamboo forests from year 1961 to 1978 was recorded (Okutomi et al., 1996), with similar increases reported in Brazil and India (Kudo et al., 2011; Lima et al., 2012; Dutta and Reddy, 2016; Kudo et al., 2018). In a survey carried out using satellite images from 1973 to 2012, nearly $21 \%$ of evergreen forests in Western Ghats has shown to be invaded by a native reed bamboo, Ochlandra travancorica (Dutta and Reddy, 2016). A similar development was also reported in India with another native bamboo species, Yushania maling (Roy et al., 2016; Srivastava et al., 2018). These long-standing figures clearly highlight the ability of some bamboo species to expand their territories irrespective of their ecological status.

It seems that both exotic and native bamboos contain similar plant attributes to facilitate their 'invasive' behavior viz., rapid growth, clonal reproduction, phenotypic plasticity, competition and allelopathy (Yang et al., 2015). Despite their rare flowering events and subsequent seed production, the ability of bamboos to reproduce through clonal stems together with their inherent rapid growth have transformed them into aggressive invaders. With flowering cycles far apart, bamboos mainly spread through clonal growth (Xu et al., 2020). In addition to their inherent attributes, bamboos also take advantage over other co-occurring species by making their immediate environment inhospitable for others to sustain. With long culm lengths and high crown position, bamboo species, such as $P$. pubescence, are able to penetrate the canopy of broadleaved forests casting a significant shade over the forest floor, transforming the forest undergrowth unfavorable for emerging seedlings and their survival (Isagi and Torii, 1997). Studies also observed that some bamboo species thrive in clay-rich soils while others prefer rocky slopes with southerly, southeasterly or easterly aspects (Lima et al., 2012; Ying et al., 2016; Wijewickrama et al., 2019). The extant vegetation and land use, and spatial and topographic features are identified as main contributory factors for $P$. pubescens invasion (Suzuki, 2015), suggesting the importance of both intrinsic and extrinsic factors that may facilitate their population expansion.

The ability of plants to adjust to suit changing conditions (i.e. plasticity) is a crucial attribute in exotic species to determine their invasive success (Hodge, 2014). Bamboos too have shown their ability to adjust to moving conditions (Montti et al., 2014; Winkler et al., 2016). Some woody bamboo species show high plasticity in terms of structural and functional leaf traits in response to different light conditions (Montti et al., 2014), while others showed a greater plasticity in response to physical and physiological stress (Lima et al., 2012). High plastic nature seems to play a crucial role in determining the invasive potential of 'native' bamboos as well. However, the dearth of studies on bamboos and their potential eco-physiological traits under varying environmental conditions can be highlighted as a drawback in concluding and predicting their invasive behavior despite their 'native' status. 
External factors responsible for sudden expansion of bamboo

Human-induced environmental changes are known to modify vegetation dynamics (Franklin et al., 2016). Available research is mostly focused on gradual decline of plant populations or extinctions triggered by environmental changes (Chang et al., 2015), while overlooking population expansions. Both anthropogenic and/or natural disturbances are identified as main drivers accountable for range and compositional shifts in plant communities, in which the 'less tolerable' species (or 'losers') tend to decline and are replaced by 'more tolerable' species ('winners') (McKinney and Lockwood, 1999). Exotic species are considered as 'winners', while the 'natives' often go unnoticed (Mack et al., 2000; Stohlgren et al., 2008). While species invasion and habitat modifications are identified as major causes for the decline of native species (Didham et al., 2007), much studies have not been done to ascertain the actual causes of their rapid expansion in home ranges. Regular and mild anthropogenic disturbances are known to play a crucial role in shaping the structure and composition in communities (Sheil, 2016), but when they exceed a certain threshold level (in terms of magnitude, timing, and variability), they seem to trigger a population expansion of some native species (Catford et al., 2012; Pivello et al., 2018). Accordingly, some speculate that anthropogenic and natural disturbances and their interactions may also assist sudden population expansion of bamboos, though their precise underlying mechanisms are not yet fully understood (Bai et al., 2013).

The climate change is identified as one of the causes of modifying plant populations and communities (Chang et al., 2015). In favour, phenological and range shifts in plants (and animals) are observed in parallel with the anthropogenic global warming (Parmesan and Yohe, 2003; Lenoir and Svenning, 2015). Climate change influences plant species differently (Lewis et al., 2004; Zuidema et al., 2013), where highly abundant species are prone to decrease their population growth rates (Chang et al., 2015), while highly localized populations, such as native bamboos, tend to expand. However, there is no solid evidence to support that range shifts of some species are solely driven by temperature-induced causes, such as dispersal behavior, mortality and survival (Parmesan and Yohe, 2003; Parmesan, 2006). Considering all these facts, it can be hypothesized, that once the dominant species in forest communities decline or shift their ranges due to climate change or its related factors, other opportunistic species such as bamboo with high tolerance to extreme climatic conditions and rapid growth take advantage of the situation, thus expanding their populations in an unprecedented manner.

Human activities are also known to trigger native species to expand populations in home ranges (Carey et al., 2012). These population growths sometimes may go unchecked causing alterations in dominance hierarchies in plant communities (Goodrich and Buskirk, 1995; Valery et al., 2008). Thus, human-mediated habitat changes may drive individual effect of native species (both plants and animals) on its resident community, increasing the levels of predation and competition. Such situations may facilitate the native species to become dominant in the community by exploiting and filling vacant niches that left behind by other native species (Didham et al., 2007). The changes to dominance hierarchies of plant/animal communities cause substantial modifications to the biotic component and its interactions, if the new dominant species is drastically differed from the former (Larpkern et al., 2011). This could be another possible scenario of how some native bamboo species are becoming dominant in their home ranges.

A study carried out in a mixed deciduous forest in Northeastern Thailand suggests that human-induced disturbances be responsible behind expansion of Bambusa tulda and Cephalostachyum pergracile populations, causing significant changes to the extant woody vegetation. Though some support the notion that human-mediated disturbances cause bamboos to expand (Tripathi et al., 2006; Yang et al., 2015), others do not. A study carried out in China reported a population expansion of a native moso
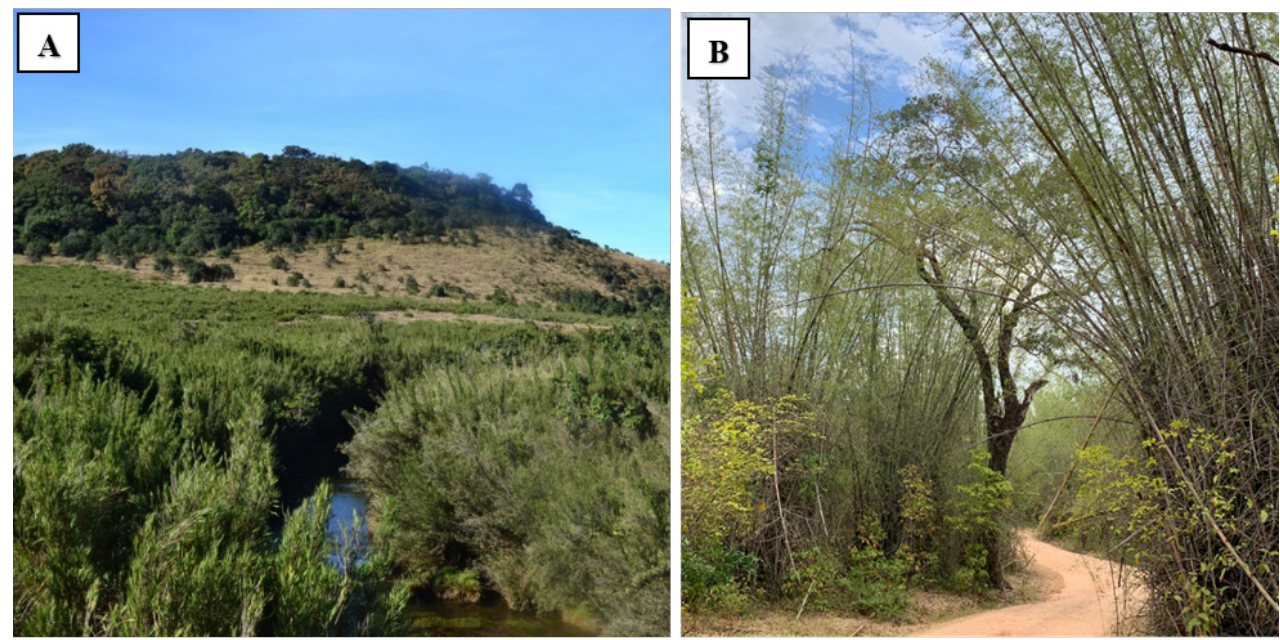

Figure 5: A: Kuruna densifolia (an endemic), B: Bambusa bambos (a native) are expanding their populations in the Horton Plains National Park in the Central Highlands and Minneriya National Park, North Central Province of Sri Lanka, respectively. (C) Tharanga Wijewickrama and Imesh Weerasinghe. 
bamboo species with no apparent human interventions, suggesting the complexity of the present understanding of native invaders (Bai et al., 2016).

Despite some positive relationships of humaninduced drivers and species declines/extinctions and/or shift ranges (Franklin et al., 2016), concrete evidence to support this theory is still scarce. Few studies speculate a connection between human-induced drivers and sudden expansion of plant populations, and even identify climate change as the most significant causal factor (FernandezGoing et al., 2012; Conlisk et al., 2013; Vanderwel and Purves, 2014). However, it is right to suggest that bamboos are particularly more vulnerable to climate change due to their lack of ability to adapt as a result of unusually lengthy flowering cycles and rather limited seed dispersal ability (Taylor et al., 1991). In favour, a study carried out in China observed a climate-driven reduction of three bamboo species causing adverse consequences on the panda population (Tuanmu et al., 2013). Kuruna densifolia (an endemic) and B. bambos (a native) are expanding their populations in highly protected areas in Sri Lanka, further supporting the pivotal role played by the climate change for their invasive behaviour where human disturbances are minimal (Figure 5).

In addition to human-mediated causes, other factors are also debated in order to explain sudden expansion of bamboo populations. Bamboos produce nutritious seeds with no known toxicities, hence making them a good food source for animals (Chatterji, 1960). During masting events, the seed predators of bamboos thrive, expanding their populations and at the same time aiding the expansion of bamboos. In addition, massive seed production and rapid growth, the absence of large mammals predate on bamboo seeds, seedlings, and their young shoots may also indirectly help bamboos to expand their populations (Galetti et al., 2009). Fire is another driving force that seems to assist the expansion of bamboo into neighboring areas. A study carried out in Guadua sarcocarpa dominated forests in the South-West Amazon concludes that forest fires could expedite the bamboo spread (Smith and Nelson, 2010). In favour, da Silva et al. (2021) also concludes that droughtinduced forest fires can shift these tropical lowland forests towards bamboo-dominated forests, with the caution of the possibility of this becoming even worse with more frequent fires owing to global warming.

Suzuki (2015) justly highlights the complex nature of this issue by emphasizing the interactive nature of biotic and abiotic factors that may facilitate the expansion of bamboo. Ying et al. (2016) noted that evergreen broadleaf forests are more prone to moso bamboo ( $P$. pubescencs) invasion than deciduous broadleaf and coniferous forests, suggesting their preference for specific edaphic and microclimatic conditions to further expand. The plastic nature of bamboos (both morphological and physiological) to environmental parameters such as soil moisture (i.e. a dwarf bamboo, Sasa kurilensis), could also play a pivotal role in their rapid expansion (Winkler et al., 2016). Some bamboo species (i.e. Guadua tagosra and Bambusa bambos) seem to prefer clay-rich soils for their establishment (Lima et al., 2012; Wijewickrama et al., 2020), while major flood events coincide with mast seeding may also contribute to population expansion of bamboo species, Merostachys riedeliana (Oliveira-Filho et al., 1994). The succeeding micro-climate changes driven by forest fragmentation (such as light and soil moisture) have been identified as probable facilitators for range expansion of a dwarf bamboo species, Sasha chartacea (Tomimatsu et al., 2011). Allelopathy is known to aid plants to expand territories in both native and introduced ranges. A native bamboo species, Merostachys riedeliana that overabundant in Brazilian Atlantic Forests, has shown high to moderate allelopathic activity, thus earmarking as one of the major underlying causes for its superior ability to expand (Jose et al., 2016). The overall evidence displays the complexity of underlying mechanisms contributing to population expansion of native bamboo invaders.

\section{Bamboo driven ecological impacts}

From time to time, scientists have justly pointed out the importance of deliberating on 'native invaders' and their potential impacts on home ranges (Carey et al., 2012; Yang et al., 2015; Pivello et al., 2018). It is valid to suggest that when native species expand their populations in home ranges, they consume the available resources at the expense of other co-occurring species, thus causing them to decline (Arim et al., 2006). Such 'super-dominant' species may influence not only the structure and composition of its resident community, but also some vital functions, such as pollination, seed dispersion and nutrient cycling, thus converting the ecosystem into a new realm. These changes together with subsequent micro-climatic modifications influence the natural regeneration of the community causing long-term irreversible changes (Simberloff et al., 2012). Therefore, it is vital to detect these 'native invaders' in their early stages and their potential influences in order to introduce strategies to overcome any detrimental changes in their home ranges.

Despite some evidences to support that overdominance of bamboos influence crucial community parameters and processes, information on short- and long-term impacts in different habitat-climate settings is relatively scarce due to lack of attention on 'native' invaders. In the recent past, studies have been carried out in countries, such as China, Japan and Brazil, exploring possible impacts of over-dominance of bamboos, with more focus on extant vegetation and some edaphic properties. Ecosystem functions, such as nutrient cycling, seedling recruitment, regeneration potential and soil biology, have enticed relatively poor attention. Therefore, these crucial aspects need to be explored in order to determine overall effects of bamboo over-dominance on home ranges.

\section{Vegetation characteristics}

Biomass, density, and diversity

Whether it is a native or an exotic, single-species dominance could inflict modifications to its plant community by altering the structure, composition and diversity. The diffusing nature of woody bamboos and their mass flowering events 
alter the micro-environmental conditions in their invading habitats. These micro-environmental changes could eventually trigger long-term structural and compositional changes in forest communities (Budke et al., 2010). The rapid growth of bamboos and their high competition for resources may add new dimensions to this issue. Larpkern et al. (2011) observed a decrease in woody seedling abundance, richness and diversity in bamboo-dominated forests, highlighting it as a clear sign of altering the structure of the extant vegetation in time. Bai et al. (2013) also observed a negative effect on plant diversity as a result of moso bamboo invasion in a coniferous, broadleaved forest in China. Lima et al. (2012) noticed a lower density of mature trees and species richness in an Atlantic forest dominated by a native bamboo species, Guadua tagoara. Long-term study in Southern Brazil indicates a low species diversity that fluctuates greatly over time in comparison to bamboo-free Araucaria forests (Lacerda and Kellermann, 2019). A lower recruitment rates together with high mortality seem to be major contributory factors for lower abundance of mature trees in bamboo-dominated communities. In Brazil, the forest gaps created by dieback events of Merostachys skvortzovii have facilitated the reestablishment of light-loving bamboos, thus exerting a negative influence on the tree seedling emergence (Greig et al., 2018). Several other studies too observed a decline in diversity due to over-dominance of bamboos (Larpkern et al., 2011; Kudo et al., 2017). In contrast, an increase in plant diversity was observed in a study done in Sri Lanka (Wijewickrama et al., 2020), though the increase is due to the establishment of light-loving non-forest species facilitate by bamboo-driven micro-climatic modifications. However, the same study detected no marked difference in tree densities in native forest patches with and without B. bambos.

The above-ground biomass is another crucial indicator of ecosystem health in forests. Bamboodominated forests show lower plant biomass in comparison to non-bamboo forests (Griscom and Ashton, 2003; Lima et al., 2012), while others reveal a higher annual biomass in moso bamboo forests in comparison to subtropical forests in China (Zhou and Jiang, 2004). A significantly greater net primary productivity in bamboo-dominated forests in comparison to nearby secondary evergreen broadleaved forests was observed by other workers too (Xiao et al., 2007; Xie et al., 2014). These findings suggest that bamboo dominance impose contrasting effects on forest communities which mainly depend on differences in climate-habitat settings thereby discouraging any over-simplification of bamboo-driven impacts without considering other on-site characteristics.

\section{Species composition}

The over-dominance of bamboos alters the species composition in both natural and semi-natural forests (Tabarelli and Mantovani, 2000; Griscom and Ashton, 2003; Guilherme et al., 2004; Larpkern et al., 2011), encouraging structural modifications over time. The bamboo-driven structural changes in forest communities are generally triggered by changes to tree recruitment and tree mortality (Guilherme et al., 2004). Bamboos do not affect all forest species and their maturity stages alike (Lacerda and Kellermann, 2019; Fadrique et al., 2020). Tall canopy and pioneer trees are the least affected as they both have the ability to break free from the dominance caused by bamboos, while the understory trees suffer the worst. Canham and Marks (1985) observed that bamboos facilitate seedlings of certain species while discouraging others. Wijewickrama et al. (2020) also observed a similar selective effect where $B$. bambos dominance favours lightloving species while discouraging shade-loving forest species under its canopy. Such species-specific preferences, encouraged by micro-climatic modifications to the forest interior due to bamboo dominance, may eventually lead to alter the composition and structure of bamboo-rich forest communities over time (Okutomi et al., 1996; Gonzalea et al., 2002; Lima et al., 2012).

\section{Tree mortality}

The mortality incidences have been intensified globally over the past few decades lowering the quality of forest communities. The most frequently implicated factors for forest dieback are elevated temperature, drought/water stress and air pollution. In a local scale, high tree mortality incidences in forest communities have been associated with both natural and anthropogenic causes including altered microclimatic conditions, wind turbulence, lianas and bamboos (Laurance et al., 2000; Nascimento and Laurance, 2008; Medeiros et al., 2013). Recent studies highlight a close link between bamboo-dominance and tree mortality, where bamboos seem to inflict direct and/ or indirect impacts on trees leading to their early deaths [(Laurance et al., 2000; Ferreira et al., 2020; Wijewickrama et al., 2020; Fadrique et al., 2021), Figure 6]. Bamboos are known to inflict more damage on late successional species than pioneers (Swaine and Whitmore, 1988). Though the precise mechanism is still not known, different hypotheses are set forth to explain this disturbing phenomenon in bamboo-dominated forest communities. According to Ferriera et al. (2020), the regular die-offs in bamboo forests accumulate high fuel loads triggering forest fires during dry seasons killing canopy trees. This hypothesis has been favored by previous workers as well (Keeley and Bond, 1999; Veldman and Puts, 2011), suggesting forest fires as one of the major causal factors for high mortality in bamboo forests.

Though tree mortality and bamboo density are factors known to relate closely (Medeiros et al., 2013), the potential bamboo-driven effects and their underlying mechanisms may vary between ecosystems and species (Fadrique et al., 2021). According to literature, physical damages from falling bamboo culms, changing microclimate, selective regeneration, allelopathy and edaphic factors are also implicated as possible causal factors for tree deaths in bamboo forests (Griscom and Ashton, 2003; Campanello et al., 2007; Montii et al., 2011; Jose et al., 2016). Though lianas are an integral component in tropical forests, they are known as 'structural parasites' owing to their ability to compete for resources (Swaine and Grace, 2007; Schnitzer and Bongers, 2011). When the lianas 


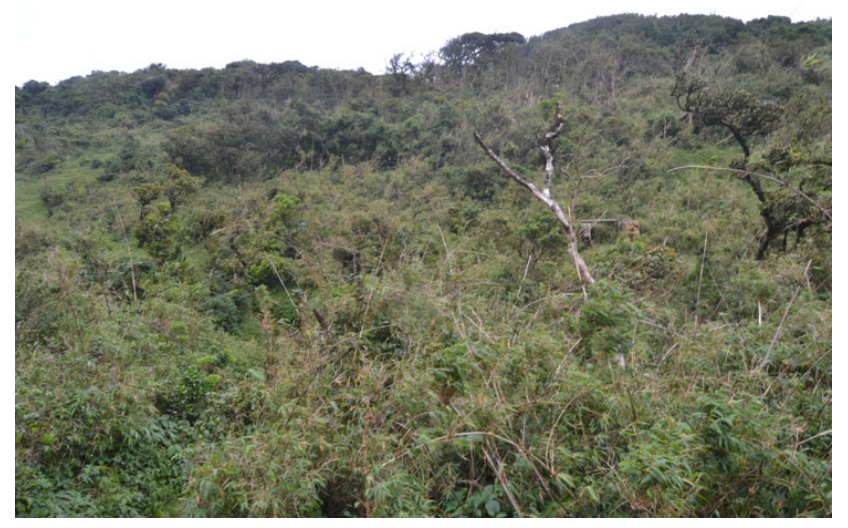

Figure 6: A spread of Davidsea attenuate, a native bamboo species, in lower montane forests in the Knuckles Conservation Area in Sri Lanka. High prevalence of forest die-back patches is also reported in these forests, prompting speculation that there is a connection between bamboo over-abundance and forest die-back. (C) Tharanga Wijewickrama.

are increased, they start competing with trees for resources, eventually causing their untimely death (Schnitzer and Bongers, 2002; Schnitzer and Carson, 2010). In favor, Wijewickrama et al. (2020) observed a higher prevalence of lianas in bamboo-rich forests in Sri Lanka, where high tree mortality incidences were also recorded in comparison to nearby non-bamboo forests.

\section{Ecosystem functions}

The bamboo-driven impacts are not only confined to the above-ground features of the vegetation but also on ecosystem functions, such as natural regeneration, decomposition rates and nutrient cycling (Liu et al., 2000; Parsons and Congdon, 2008). However, as mentioned previously, comparatively less number of studies has been carried out to explore impacts on ecosystem functions following bamboo over-dominance (Bona et al., 2020).

\section{Nutrient cycling}

Exotic invaders are known to modify soil nutrient pools and their dynamics through altered litter production, litter quality and decomposition rates (Harner et al., 2009; Sharma and Raghubanshi 2009; Piyasinghe et al., 2019). However, similar studies lack on 'native invaders' (Bai et al., 2016). Litter production, quality and decomposition, and decomposer communities are known to impose overriding impacts on nutrient cycling processes in communities. Exotic invaders produce high quality and quantity of litter, with a high chance of influencing nutrient dynamics (Liao et al., 2008; Kurokawa et al., 2010; Zhang et al., 2013). In contrast, native invaders including bamboos produce poor quality litter compared to that of broadleaved species (Liu et al., 2000; Fukushima et al., 2015; Song et al., 2016), thus anticipating impacts different to that of exotic counterparts. Apart from mass die-off events, bamboo-dominated forests recorded a lower litter production (in terms of dry weight basis) in comparison to adjacent broadleaved forests (Song et al., 2016; Wijewickrama et al., 2021). During mass dieoff events, bamboos produce large amounts of litter thereby causing significant impacts on biogeochemical cycles and nutrient pools.

Liu et al. (2013) observed a higher soil total $\mathrm{N}$ content in bamboo forests than that in evergreen broadleaved forests. In contrast, Song et al. (2017) observed a decelerated nitrogen cycle in an evergreen broadleaved forest in the sub-tropical China following a native bamboo invasion (Phyllostachys pubescens), indicating a risk of decline in soil fertility status over time. Shen (2015) observed an increased nitrogen mineralization and nitrification following a spread of bamboo in a broadleaved forest. These conflicting findings suggest the importance of further deliberations on bamboo-driven nutrient cycling processes through comprehensive research. Austin and Marchesini (2012) observed a negative impact on carbon and nutrient cycles due to slow decay of bamboo litter, confirming the crucial role of decaying rates on nutrient dynamics (Fujimaki et al., 2008; Tu et al., 2014; Song et al., 2016). Other studies also observed poor mass losses in bamboo litter compared to that of broadleaved forest species (Liu et al., 2000; Tripathi et al., 2006; Fujimaki et al., 2008). Overall, low quality and quantity of litter together with diminished decomposition rates can instill negative impacts on biogeochemical cycles following bamboo invasions.

\section{Biotic interactions}

Seed dispersal mechanisms are decisive factors in determining plant composition and diversity in forests. Plants provide resources for seed dispersers thus any constraints to seed dispersal mechanisms could jeopardize the natural succession of forests (Holl, 1999). In addition, the availability, quantity and richness of the seed rain are key factors maintaining the natural regeneration process. The bamboo-induced changes to light levels in the forest floor and their mass flowering and die-off events could alter trophic interactions including seed dispersal, predation and herbivory (Kitzberger et al., 2007; Giordano et al., 2009; Marchesini et al., 2009). In a recent study by Bona et al. (2020), a low seed richness was observed in bamboodominated forests (a native bamboo, Guadua weberbaueri) that would eventually lead to notable compositional differences among bamboo- and bamboo-free forests.

\section{Forest regeneration}

Bamboos influence the natural regeneration in two different ways; (i) through changes in micro-habitat caused by overdominance and (ii) changes caused by their unusual fruiting events followed by mass die-offs. Oddly, both scenarios alter micro-environmental conditions in the forest interior in conflicting ways. As an example, the over-dominance of bamboos may reduce the light intensity in the forest interior while the mass die-offs would increase it. These conflicting modifications affect the natural regeneration in the forest, deviating from its normal trajectory and incurring long-lasting changes in the forest structure. Furthermore, soil seed bank and seedling recruitment may also use as evidence to predict changes to regeneration potential (Vandvik et al., 2016), though few studies have 
been carried out in forests invaded by native bamboos (Wijewickarama et al., unpublished).

Prematilleke et al. (2008, 2015) reported that Ochlandra stridula, an endemic bamboo species in the wet zone of Sri Lanka, hinders forest regeneration due to its rapid expansion (Figure 1). This is the first account in the country raising awareness on potential threats of 'native' invaders to forest communities. This work attracted criticisms from the scientific community as the focal plant is an 'endemic' instead of an 'exotic', which has challenged the 'norm'. However, since then, more studies have been undertaken globally acknowledging that even native/ endemic plants could become invasive in their home ranges bringing negative consequences, perhaps similar to exotic invaders (Pivello et al., 2018).

Shading effect, physical damage to saplings, exposure to frequent fires and heavy litter accumulation have been proposed as possible causes for the decline in regeneration potential (especially trees) in bamboodominated forests (Oliveira-Filho et al., 1994; Silman et al., 2003; Griscom and Ashton, 2006). Woody bamboos are known to influence the forest structure and dynamics by casting a shade on the forest understory (Guilherme et al., 2004), while at the same time providing a favourable micro-habitat for seed predators (Iida, 2004). Low sunlight in the forest understory and high incidence of seed predators may incur negative influence on tree seedling recruitment, growth and their survival, with the possibility of disturbing the natural forest succession (Griscom and Ashton, 2003; Campenello et al., 2007). Due to the absence of fleshy fruits, bamboos attract less seed dispersers which could also influence the seed rain negatively. In Brazil, a severe inadequacy of seeds was noted in bamboo-dominated forests over non-bamboo forest stands explaining the poor seedling recruitment in the latter (Rother et al., 2009). In contrast, a study carried out in Sri Lanka observed that $B$. bambos-dominated forest patches had more seedlings but with the least representation from tree seedlings (Wijewickrama et al., 2021). Rother et al. (2018) too observed a higher seedling abundance and emergence under the bamboo canopy than of forests without bamboo, though the diversity is less. These findings further support the tendency shown by bamboo-dominated forests to modify their species composition and structure over time.

As bamboos tend to grow fast and produce high biomass, bamboo-rich forests get more litter (in terms of the thickness of the litter layer) in comparison to broadleaved native forests. Surface litter may incur contrasting impacts in the forest regeneration potential based on species-specific requirements (Larpkern et al., 2011; Rother et al., 2016). A thick litter layer may inhibit seed germination due to lack of sunlight (Facelli and Picket, 1991), and at the same time, increasing the abundance of pathogenic fungi due to improved humidity (García-Guzmán and Benítez-Malvido, 2003). The accumulation of light-weighted bamboo litter may also increase the risk of forest fires especially during dry periods (Wijewickrama et al., 2019), incurring detrimental impacts on emerging seedlings. Massive flowering followed by mass dieback events in bamboo may also influence the natural regeneration (Gonzalez et al., 2002; Rother et al., 2009), through modifying germination rates and seedling mortality (Brokaw and Busing, 2000; Budke et al., 2010). Mass death events in bamboo alter micro-environmental conditions markedly, in terms of light and temperature, which are considered as decisive factors influencing the regeneration process (Budke et al., 2010; Capellosso et al., 2016).

\section{Edaphic properties}

\section{Soil nutrients}

Invasion driven changes to edaphic properties are understudied in comparison to above-ground parameters (Millangoda and Madawala, 2018). In plant communities, the litter production, litter chemistry and their decay rates are overriding factors that determine changes in soil nutrients over time (Giebelmann et al. 2013). Bai et al. (2016) reported a decrease in soil organic carbon and nitrogen in upper soil layers following bamboo dominance in a study carried out in Southern China, while others noted an increase in N (Chang and Chiu, 2015; Chang et al., 2018). Poor quality and low production of bamboo litter are identified as factors responsible for decrease in $\mathrm{N}$ mineralization rates thus causing a low availability of soil N (Song et al., 2016). In contrast, others demonstrated an increase in soil organic $\mathrm{C}$ and $\mathrm{N}$ following bamboo expansion (Wu et al., 2008; Song et al., 2013; Wang et al., 2017), indicating the lack of consistency in findings. Wijewickarama (2020) observed no marked changes to soil nutrients in a comparative study carried out in bamboo and non-bamboo forest patches located in the intermediate climatic zone in Sri Lanka. These conflicting results question the ability of some bamboo species to change the soil nutrient status while others tend to colonize preferably in nutrient-rich soils. In a seedling assay carried out with Ricinus communis, seedlings performed better in bamboo soils than that of non-bamboo soils further speculating the ability of bamboos either to enhance the soil fertility status or establish specially on nutrient-rich soils (Millangoda and Madawala, 2018). Liu et al. (2019) rightly discouraged the oversimplification of bamboo impacts on soils as the severity and the time duration of the invasion, together with other site-specific inherent factors may vary between communities and sites.

\section{Soil microbes}

Soil microbes are major drivers of soil nutrient dynamics and are sensitive to vegetation-driven changes ( $\mathrm{Xu}$ et al., 2020). The intimate relationship between the above-ground vegetation and the below-ground microbiota is rather a well-established fact highlighted by scientists. Accordingly, any changes to the above-ground vegetation could trigger comparable changes to the below-ground communities. Exotic invaders have shown to alter the structure, composition and richness of soil microbes (Madawala, 2014; Stefanowicz et al., 2019; Bani et al., 2018; Mafaziya et al., 2019). Despite having ample evidence to suggest that exotic invaders modify soil microbiota, fairly few studies are available to explore potential impacts of native invaders 
(Xu et al., 2014; Xu et al., 2015; Mafaziya et al., 2019; Tian et al., 2020). The limited number of studies done on bamboo-driven influence on soil microbes indicate somewhat contradictory findings to that of exotic invaders. Interestingly, a study carried out in bamboo-invaded native forests in China has shown that moso bamboo dominance has increased the microbial biomass and taxonomic diversity despite a decrease in above-ground diversity $(\mathrm{Xu}$ et al., 2015). In favour, a study carried out in Sri Lanka witnessed a higher abundance and richness of AMF following a population expansion of native $B$. bambos, with no apparent changes to its community structure (Mafaziya et al., 2019). Tian et al. (2020) observed a decline in fungal diversity following a moso bamboo invasion in a subtropical forest in China, with no marked impact on the bacterial diversity, suggesting that fungi be more sensitive to bamboo invasions than its bacterial counterparts. However, the limited studies may not allow reaching any solid conclusions on how bamboos modify soil microbial populations.

\section{Fauna}

There is evidence to believe that single-species dominance could alter the richness and distribution of many critical faunal groups. Watling et al. (2011) reported that a native frog species, Lithobates clamitans, has been adversely affected after altering the micro-climate following the shrub invasion of Lonicera maackii. A meta-analysis also confirmed comparable findings in terms of arthropods (Hengstum et al., 2014). Invasions are known to impose behavioral changes in native animals through interference/ competition, heightened risk of predation and modifying habitats (Byers, 2000; Tuomainen and Candolin, 2011). In parallel, when a native invader expands its population in a hasty manner at the expense of other co-occurring species, similar effects could also be anticipated on native fauna. Being a major component in forests, bamboos provide food and shelter for many animals, including one of the most endangered species on earth, the giant panda (Schaller et al., 1985; Pan et al., 2001) and providing evidence for their long history in the co-evolution.

The mass dieback event in bamboo may also threaten some animal species that exclusively depend on them. Giant panda (Ailuropoda melanoleuca), red panda (Ailurus fulgens), the Himalayan black bear (Selenarctos thibenatus) and the smallest known bat (Tyloncteris pachypus) are some known animals that depend solely on bamboos for their nourishment and survival (Bystriakova et al., 2003). Furthermore, more than 15 rare and threatened bird species in Asia have chosen bamboos exclusively as their roosting habitat (BirdLife International, 2000). Such specialized relationships between animals and bamboos highlight the subtle balance between them.

Yang et al. (2008) observed a drastic reduction in richness and abundance of birds in a native broadleaved forest following a bamboo invasion. In contrast, a study conducted in Brazil showed an increase in the avifaunal richness following an expansion of a native bamboo species (Guadua tagoara), possibly due to the sudden availability of ample food and perches (Rother et al., 2013). The high heterogeneous environment in bamboo forests due to their patchy distribution seems to favor the avian population. The scarcity of studies and existing contradictory findings are major hindrances to reach solid conclusions in bamboodriven impacts on fauna.

Mass death events in bamboo forests can lead to create gaps in forests triggering significant changes in the microclimate of the forest undergrowth (Campanello et al., 2007; Budke et al., 2010; Montii et al., 2011; Capellesso et al., 2016). Ground-dwelling insects are highly sensitive to environment and substrate modifications (Moldenke et al., 2000). As arthropods thrive on specific substrates for feeding and breeding, any changes to above-ground vegetation may incur significant changes to the composition and structure of litter-dwelling arthropods (Bernays and Graham, 1988). The potential bamboo-driven changes to micro-environment of the forest floor (light intensity, temperature, and soil moisture) could trigger changes in the mobility, distribution and reproductive success of litterdwelling arthropods (Wolkovich et al., 2009; Talley et al., 2012). A study conducted in Sri Lanka also confirms that $B$. bambos spread has increased the abundance and richness of litter-dwelling arthropods perhaps due to the sudden availability of a suitable substrate for their sustenance and survival (Wijewickrama et al., unpublished). Therefore, sudden expansion of native bamboo populations and their die offs may cause a significant influence on grounddwelling faunal groups (Davidson et al., 2006; Jacobs et al., 2018), but the lack of research restraints in reaching firm generalizations. The impacts of bamboo on soil fauna and their interactions seem to vary among faunal groups (Liu et al., 2021), further reiterating the necessity of more studies.

\section{Bamboo-dominated forests: their management}

Similar to 'exotic' invaders causing serious environmental and societal issues worldwide, the 'native invaders' have also laid down grave challenges to scientists, conservationists, policymakers, and the communities living close to these forests. However, due to many reasons, this issue has not been given due recognition by the authorities. Therefore, the scientific knowledge on 'native' invaders is mandatory outside the existing knowledge on 'exotic' invaders in order to find answers to their exclusive life traits that facilitate their ability to invade home ranges and to introduce new strategies to manage them effectively. As 'native' invaders have many economic uses, controlling, and managing them could pose added challenges unlike the 'exotic' invaders, which are well-known for their damaging impacts. As they are 'natives', it is still not clear whether they can cause long-term detrimental impacts on their home ranges or their impacts are short-lived. Thus, short-term as well as long-term studies are imperative to understand their life traits and potential behaviours. However, making the general public and communities aware of potential threats of 'native' invaders could be a crucial step towards getting rid of societal challenges before prioritizing goals and earmarking management strategies. 


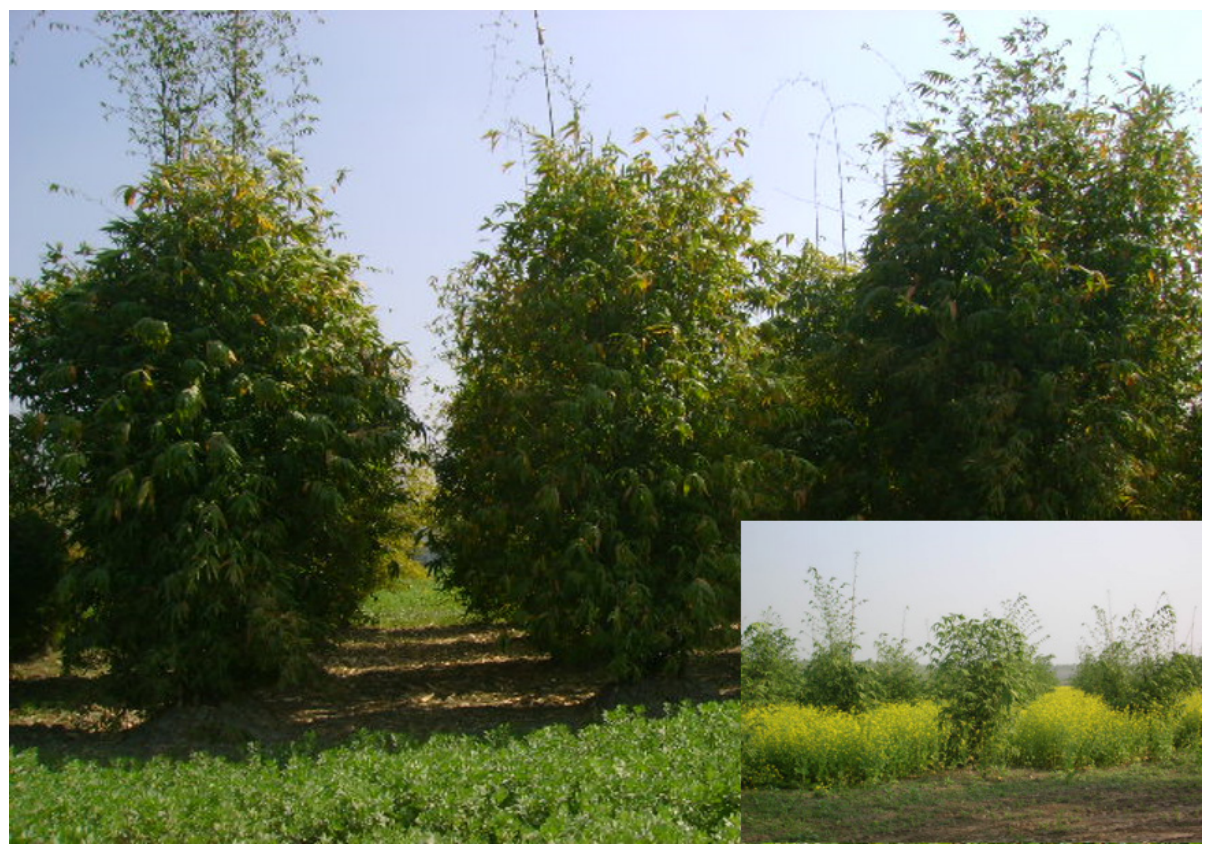

Figure 7: A plantation of Bambusa balcooa (a native clumping bamboo species) in India. It intercrops with mustard (inset). B. balcooa has many commercial uses including wood chip industry, building material, raw material for fishing and agricultural implements, paper pulp etc. Shoots are consumed as a vegetable and leaves as a fodder. (C) Prof. Salil Thewari, G.B. Pant University of Agriculture and Technology, Pantnagar, Uttarakhand, India.

It is startling to observe the gradual increase of bamboo forests while the native forest cover declines at a steady annual rate (Ferreira et al., 2020). Some countries introduce bamboo plantations to use as a renewable resource, and for other ecological and economic returns. Therefore, careful planning and management interventions are imperative when establishing 'exotic' or 'native' bamboo species for commercial use. The management and mitigation measures of 'exotic' invasions have been amply evaluated and tested under different habitat and climatic conditions. However, a comparable attention has not been given for 'native' invaders. Despite possible similarities in their likely impacts ('exotic' and 'native' invaders), comparable approaches may not be feasible due to marked differences in their ecological status, other life traits and possible impacts. Therefore, specific management interventions need to be identified for 'native' invaders and tested under different field and climatic conditions before use them in large-scale missions.

Unlike other 'native' invaders, bamboos are extremely adaptable and competitive, making them good contenders for invading fragile habitats. Their ability to spread through rhizomatous growth adds a new dimension to this problem. Therefore, imposing physical barriers can be considered as an effective measure to restrain their expansion through clonal growth (Isagi and Torii, 1997). However, erecting physical barriers could only be feasible for small-scale bamboo plantations or forests. A success story is reported from China where the bamboo spread is controlled through manual methods (Ying et al., 2016; Kudo et al., 2017), in a trial carried out in small experimental plots. Therefore, similar outcomes cannot be anticipated from large-scale areas due to the innate vigor of bamboo species and other practicalities. The selection of bamboo species with low invasive potential, avoiding susceptible areas, implementing measures to stall expansion and encouraging mix planting are some of the measures to contemplate when introducing bamboo plantations, though some of these management interventions are labour intensive and costly [(Brown et al., 1987; Li et al., 2003), Figure 7].

Bamboo forests possess a low timber potential, thus any logging activities need caution (D'Oliveira et al., 2004; Rockwell et al., 2014). The lack of scientific data and due recognition of the issue are major impediments of introducing effective strategies to manage native bamboo invaders (Rockwell et al., 2014; Buziquia et al., 2019). The lack of comprehensive studies on native bamboo invaders is perhaps due to either strain of carrying out vegetation studies in bamboo-rich forests and/or poor recognition of bamboo-rich forests from the rest of the forest types (Griscom, 2003; Phillips et al., 2003). In some countries including Sri Lanka, the bamboo invasion is highly localized, thus can be easily evaded the necessary attention from the researchers and policy makers. Some countries in the region generally highlight the positive consequences of bamboo forests more than the negative, while emphasizing its place in the high conservation priority (Tuanmu et al., 2013). Others highlight the economic values of bamboo forests and their role in alleviating environmental issues, such as soil erosion, water conservation, land rehabilitation and carbon sequestration (Zhou et al., 2005). Therefore, the negative aspects of bamboo dominance are largely concealed by their more renowned ecological and economic returns, prompting more challenges to address this issue. During the past decade, more studies have come to the forefront highlighting their negative ecological impacts in their introduced/native ranges and their discreet ability to 
invade adjoining landscape, suggesting physical removal as the only solution to restrain those (Bai et al., 2013).

In order to exploit bamboo resources in a sustainable manner while introducing effective management strategies, it is crucial to know their extent of distribution (Yang et al., 2016). The quantification of bamboo resources is also important as they have many economic uses. A study conducted in Western Ghats in India to explore spatial and temporal trends of a native reed bamboo population of Ochlandra travancorica is reported that nearly $21 \%$ of bordering evergreen forests has been transformed into pure bamboo stands over the years (Dutta and Reddy, 2016), highlighting the severity of the problem. These alarming findings prompt the importance of long-term monitoring of growth and spread of bamboos using techniques such as GIS and remote sensing, to ensure tracking their expansion in a more effective manner.

Overall, baseline information on bamboos, their extent and distribution, and potential impacts are lacking, challenging their effective control and sustainable management. Therefore, further research is required to fill the existing knowledge gaps on invasive bamboos and their potential impacts in order to find solutions to their adverse consequences. Climate-driven responses and adaptations, characteristics of bamboo-forest interface, inherent traits, and underlying mechanisms in facilitating bamboo expansion are some of the crucial areas that need more scientific knowledge to explain their unusual behaviour in native forests (Yang et al., 2015; Buziquia et al., 2019), and to bring effective measures to control them. Larpkern and Totland (2011) hypothesized that the impacts of bamboo on co-occurring species may differ depend on the bamboo species and their major climatic zones, further supporting the importance of more comprehensive studies under different climate-habitat conditions to understand precise driving forces behind bamboo invasions. In countries where bamboos introduce as plantations need sturdy actions to monitor their growth to avoid any potential encroachments into nearby areas (Buziquia et al., 2019), as once they escape territories, controlling them would be rather difficult due to their robust nature.

\section{Knowledge gaps, challenges, and future ahead}

This review identified many knowledge gaps in native bamboos with invasive traits and challenges in controlling and managing their potentially less-known consequences. In addition to the basic understanding of invasive bamboos, the details of their expansion process and its underlying mechanisms, risk evaluation and management, and control strategies still lack appropriate focus and direction. It is not feasible to rely solely on information gathered on 'exotic' invasive species to address the potential consequences of 'native' invaders as their life traits, respective mechanisms and driving forces seem to differ considerably. Therefore, it is of great importance that scientists put more collective and concerted effort in identifying the exclusive behavior of 'native' invaders under different bio-climatic zones. In addition, the sustainable utilization of bamboo resources also needs due attention as it is probably the most effective and sustainable way of managing them without incurring major monetary constrains, especially in countries with poor economies (Figure 8).

Though there is sufficient evidence to show that native bamboos have the potential to expand their territories under unknown circumstances, there is a dearth of information to predict their impacts under different habitat-climate settings and also to ascertain what trigger their sudden change in growth. The lack of taxonomicdriven research in bamboo-dominated forests also makes it hard to acquire an overall depiction about their potential impacts. Up to now, the available research on native bamboo invaders has been mostly confined to the South

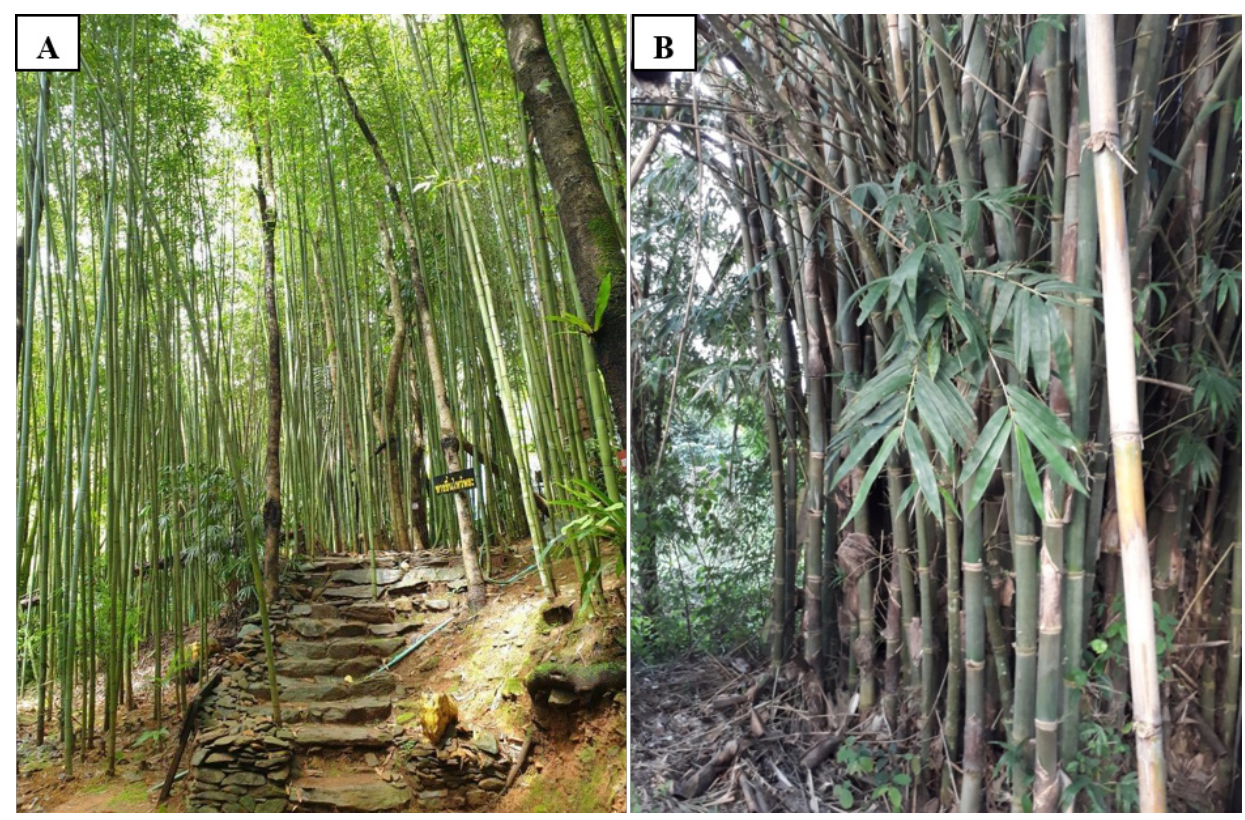

Figure 8: A: Phyllostachys sp. (a running bamboo) at Doi Chang Buddhist Park, Chiang Rai, Thailand; B: Dendrocalamus sp. (a clump forming) bamboo in Mae Fah Luang, Chiang Rai, Thailand. (C) Binu Samarakoon, Center of Excellence in Fungal Research, Mae Fah Luang University, Chiang Rai, Thailand. 
American sub-continent, China and Japan, thus making the current knowledge inconsistent and sporadic.

As a step forward, it is crucial to map the distribution of bamboo-dominated forests though it could be a major challenge to countries with low economic promise. Remote sensing (RS) and GIS are rapid and relatively accurate methods to map and quantify the distribution of natural resources. However, estimating the extent of bamboo-dominated forests is a challenging task as they grow dispersed and intermingled with other species in the forest understory with only some species reaching the canopy level (Lobovikov et al. 2007; Wang et al., 2009). These may limit the use of GIS and RS in mapping the distribution bamboo invaders (Dida et al., 2021). The application of RS in bamboo forests is rather complicated not only due to their scattered distribution but also due to the difficulty in separating them from other co-occurring forest species. There were few studies where expensive, high resolution satellite images are being used in detecting bamboos with sufficient ground-truthing (Ghosh and Joshi, 2014). In contrast, others claimed that bamboos, being an evergreen plant, could be easily detected and quantified using RS especially in the winter or in the dry season when other trees lose their green colour due to leaf senescence (Ferreira et al., 2020). Despite these challenges, there are some promising trials carried out in countries, such as China, India and Brazil, to quantify bamboo forests using RS (Bharadwaj et al., 2003; Linderman et al., 2004; Tang et al., 2016). Dida et al. (2021) carried out an extensive study to quantify bamboo resources in the Philippines, but omitting those in the forest understory due to low visibility and limited inventory data for validation. FAO (2005) highlighted the lack of consistency in terms of the quality and the reliability of data on the distribution of bamboos among countries. However, countries from the AsiaPacific region have more accurate and comprehensive data on the distribution of bamboo forests compared to that of Latin America and Africa. Overall, the statistics related to bamboos are inconsistent due to the (i) lack of systematic inventories, methodologies and techniques, (ii) their position as an understory species, (iii) lack of records due to local trade, and (iv) incompatible definitions of 'bamboo forests' among countries (Dida et al., 2021). Therefore, more steps are needed to aptly identify and categorize bamboo forests, and more studies are to be conducted to fill some of these crucial knowledge gaps to face specific challenges.

The historical information to track the chronology of bamboo expansion is crucial to demonstrate how and when a 'native' species transformed into a 'native invader' over time (Carey et al., 2012). However, historical data on bamboos are generally lacking in many countries that limits identifying what climatic factors or human/natural disturbances trigger their sudden expansion. Furthermore, the impacts of native bamboos on other populations, communities and ecosystems have not been systematically documented. Thus, studies to explore their short- and long-term impacts on biotic and abiotic factors of their respective native ranges are needed to cover as many climate-habitat combinations as possible. This information is imperative to draw the public interest in this issue and its consequences, and to introduce tangible management practices. The factors that trigger the expansion of native bamboo populations and their underlying mechanisms also need further attention by researchers. Some argue that direct human-mediated disturbances may trigger their invasive behavior, while others debate that these abrupt events are driven by climate change, fire, etc. (IPCC Climate Change, 2007). However, few studies emphasized that bamboos expand their populations unaided by human activities (Bai et al., 2016), prompting further deliberations to find evidence behind the unusual behavior of native invaders.

\section{Inferences}

Approximately a decade ago, native invasions are never heard of due to misfits in definitions. However, this issue gains momentum after recognizing the fact that native species too can become invasive in their home ranges triggered by some factors unknown to the scientific community yet. The growing scientific information on native bamboos with invasive behaviour indicates the seriousness of this issue with statistics to prove that bamboo-dominated forests are increasing at an alarming rate in a global scale. However, the lack of systematic studies on native bamboo invaders and their impacts on ecosystems sets a serious setback in managing them in a sustainable manner. The available scientific evidence suggests that bamboo over-dominance impose serious ecological impacts on biodiversity and vital ecosystem functions in their home ranges that may eventually lead to permanent modifications to resident communities over time. These effects may inflict long-term influences causing irreversible structural and compositional changes in forest communities. Many disparities in available evidence on bamboo-driven impacts suggest the gravity of oversimplification, thus highlighting the importance of comprehensive studies to cover all habitatclimate combinations. The importance of exploring the bamboo-driven impacts on below-ground resources is also highlighted. Lack of scientific and historical information is a major challenge towards introducing effective management strategies to curtail any detrimental impacts of bamboo dominance. The review highlights the arbitrary nature of scientific information and the importance of conducting further studies to fill crucial knowledge gaps on native bamboos. Introducing strategies to manage and control their harmful impacts is a crucial next step after resolving the initial challenges posed by native bamboos displaying invasive traits.

\section{ACKNOWLEDGEMENT}

Authors like to extend a special acknowledgement to Dr. Samantha C. Karunarathna, CAS Key Laboratory for Plant Diversity and Biogeography of East Asia, Kunming Institute of Botany, Chinese Academy of Sciences, Kunming, China, for assisting us identifying bamboo species and obtaining photographs from China for the manuscript. Authors would also like to extend a special gratitude to Ms. Binu Samarakoon, Center of Excellence in Fungal Research, Mae Fah Luang University, Chiang Rai, 
Thailand for taking trouble to find us suitable photographs to be included in the manuscript. The help given by Prof. Salil Thewari, G.B. Pant University of Agriculture and Technology, Pantnagar, Uttarakhand, India in finding necessary photographs is also acknowledged.

\section{DECLARATION OF CONFLICT OF INTEREST}

The authors declare that the paper does not contain any conflict of interest.

\section{REFERENCES}

Arim, M., Abades, S.R., Neill, P.E., Lima, M. and Marquet, P.A. (2006). Spread dynamics of invasive species. Proceedings of the National Academy of Sciences 103(2): 374-378. DOI: https://doi.org/10.1073 /pnas.0504272102.

Austin, A.T. and Marchesini, V.A. (2012). Gregarious flowering and death of understorey bamboo slow litter decomposition and nitrogen turnover in a southern temperate forest in Patagonia, Argentina. Functional Ecology 26: 265 - 273. DOI: https://doi.org/10.1111/ j.1365-2435.2011.01910.x.

Bai, S., Zhou, G., Wang, Y., Liang, Q., Chen, J., Cheng, Y. and Shen, R. (2013). Plant species diversity and dynamics in forests invaded by moso bamboo (Phyllostachys edulis) in Tianmu mountain nature reserve. Biodiversity Science 21(3): 288 - 295. DOI: https://doi.org/10.3724/SP.J.1003.2013.08258.

Bai, S.B., Conant, R.T., Zhou, G.M., Wang, Y.X., Wang, N., Li, Y.H. and Zhang, K.Q. (2016a). Effects of moso bamboo encroachment into native, broad-leaved forests on soil carbon and nitrogen pools. Scientific Reports 6 : 31480. DOI: https://doi.org/10.1038/srep31480.

Bai, S.B., Wang, Y.X., Conant, R.T., Zhou, G.M., Xu, Y., Wang, N., Fang, F.Y. and Chen, J. (2016b). Can native clonal moso bamboo encroach on adjacent natural forest without human intervention? Scientific Reports 6: 31504. DOI: https://doi.org/10.1038/srep31504.

Bani, A., Pioli, S., Ventura, M., Panzacchi, P., Borruso, L., Tognetti, R., Tonon, G. and Brusetti, L. (2018). The role of microbial community in the decomposition of leaf litter and deadwood. Applied Soil Ecology 126: 75 - 84. DOI: https://doi.10.1016/j.apsoil.2018.02.017.

Behari, B. (2006). Status of bamboo in India. In: India. MoEF, Compilation of Papers for Preparation of National Status Report on Forests and Forestry in India. New Delhi, Survey and Utilization Division, Ministry of Environment and Forests. 109 - 120 Pp.

Bharadwaj, S.P., Subramanian, S., Manda, S., Ray, T., Mukherjee, P. and Rao, I.V.R. (2003). Bamboo livelihood development planning, monitoring, and analysis through GIS and remote sensing. Journal of Bamboo and Rattan 2(4): 453 - 461.

BirdLife International (2000). Threatened Birds of the World. Lynx Edicions and BirdLife International, Barcelona and Cambridge.

Bona, K., Purificaçãob, K.N., Vieirac, T.B. and Mews, H.A. (2020). Fine-scale effects of bamboo dominance on seed rain in a rainforest. Forest Ecology and Management 460: 117906. DOI: https://doi. org/10.1016/iforeco.2020.117906.
Brokaw, N. and Busing, R.T. (2000). Niche versus chance and tree diversity in forest gaps. Trends Ecology Evolution 15(5): 183 - 188. DOI: https://doi. org/10.1016/S0169-5347(00)01822-X

Brown, B.J., Hanson, M.E., Liverman, D.M. and Merideth, R.W. (1987). Global sustainability: toward definition. Environmental Management 11: 713 - 719. DOI: https:// doi.org/10.1007/BF01867238

Budke, J.C., Alberti, M.S., Zanardi, C., Baratto, C. and Zanin, E.M. (2010). Bamboo dieback and tree regeneration responses in a subtropical forest of South America. Forest Ecology and Management 260: 1345 - 1349. DOI: https://doi.10.1016/j.foreco.2010.07.028.

Buziquia, S.T., Lopes, P.V.F., Almeida, A.K. and de Almeida I.K. (2019). Impacts of bamboo spreading: a review. Biodiversity Conservation 28: 3695 - 3711. DOI: https://doi.org/10.1007/s10531-019-01875-9.

Byers, J.E. (2002). Impact of non-indigenous species on natives enhanced by anthropogenic alteration of selection regimes. Oikos 97(3): 449 - 458. DOI: https:// doi.org/10.1034/j.1600-0706.2002.970316.x

Bystriakova, N., Kapos, V., Stapleton, C. and Lysenko, I. (2003). Bamboo biodiversity: information for planning conservation and management in the Asia-Pacific region. UNEP World Conservation Monitoring Centre/ INBAR, Biodiversity Series 14. UK: Swaingrove Imaging.

Campanello, P.I., Gatti, M.G., Ares, A., Montti, L. and Goldstein, G. (2007). Tree regeneration and microclimate in a liana and bamboo-dominated semideciduous Atlantic forest. Forest Ecology and Management 252: 108 - 117. DOI: https://doi.10.1016/j. foreco.2007.06.032.

Canavan, S., Richardson, D.M. Visser, V., Le Roux, J.J., Vorontsova, M.S. and Wilson, J.R.U. (2016). The global distribution of bamboos: assessing correlates of introduction and invasion. AoB Plants 9(1). DOI: https://oi.org/10.1093/aobpla/plw078.

Canham, C.D. and Marks, P.L. (1985). The response of woody plants to disturbance: patterns of establishment and growth. In: S.T.A. Pickett and P.S. White (Eds.), The Ecology of Natural Disturbance and Patch Dynamics, Academic Press, San Diego, USA Pp. 53 - 69.

Capellesso, E.S., Weirich, R., Dariva, G., Sausen, T.L. and Zanin, E.M. (2016). Influence of bamboo dieback on arboreal diversity in a subtropical forest fragment. Revista Chilena de Historia Natural 89: 1. DOI: https:// doi.10.1186/s40693-016-0054-x.

Carey, M.P., Sanderson, B.L., Barnas, K.A. and Olden, J.D. (2012). Native invaders - challenges for science, management, policy and society. Frontiers in Ecology and the Envrionment 10(7): 373 - 381. DOI: https://doi. org/10.1890/110060.

Catford, J.A., Daehler, C.C., Murphy, H.T., Sheppard, A.W., Hardesty, B.D., Westcott, D.A., Rejmanek, M., Bellingham, P.J., Pergl, J., Horvitzh, C.C. and Hulmei, P.E. (2012). The intermediate disturbance hypothesis and plant invasions: implications for species richness and management. Perspective. Plant Ecology 14(3): 231 - 241. DOI: https://doi.org/10.1016/j. ppees.2011.12.002. 
Chang, E.H. and Chiu, C.Y. (2015). Changes in soil microbial community structure and activity in a cedar plantation invaded by moso bamboo. Applied Soil Ecology 91: 1 - 7. DOI: https://doi.org/10.1016/j. apsoil.2015.02.001.

Chang, J., Wang, Y., Istanbulluoglu, E., Bai, T., Huang, Q., Yang, D. and Huang, S. (2015). Impact of climate change and human activities on runoff in the Weihe River Basin, China, Quaternary Internationals $\mathbf{3 8 0}$ - 381: 169 - 179. DOI: https://doi.org/10.1016/j. quaint.2014.03.048.

Chang, E.D., Chen, C.P., Tian, G. and Chiu, C.Y. (2018). Replacement of natural hardweek forest with planted bamboo and cedar in a humid subtropical mountain affects soil microbial community. Applied Soil Ecology 124: 146 - 154. DOI: https://doi.org/10.1016/j. apsoil.2017.11.006

Clark, L.G. and Oliveira, R.P. (2018). Diversity and evolution of the new world bamboos (Poaceae: Bambusoideae: Bambuseae, Olyreae). Keynote lecture in the $11^{\text {th }}$ World Bamboo Congress, August, 2018, Xalapa, Mexico Pp. $14-18$.

Coggins, C.R. (2000). Wildlife conservation and bamboo management in China's southeast uplands. Geographical Review 90(1): 83 - 111. DOI: https://doi.org/10.1111/j.1931-0846.2000.tb00323.x.

Conlisk, E., Syphard, A.D., Franklin, J., Flint, L., Flint, A. and Regan, H. (2013). Uncertainty in assessing the impacts of global change with coupled dynamic species distribution and population models. Global Change Biology 19(3): 858 - 869. DOI: https://doi.org/10.1111/ gcb.12090.

Da Silva, S.S., de Oliveira, I.S., Morello, T.F., Anderson, L.O., Karlokoski, A., Brando, P.M., de Melo, A.W.F., da Costa, J.G., Souza, F.S.C., de Souza, I.S., de Souza, E.N., Pereira, M.P., de Almeida, M.R.N., Alencar, A., Aragão, L.E.O.C., Brown, I.F., Graça, P.M.L.A. and Fearnside, P.M. (2021). Burning in southwestern Brazilian Amazonia, 2016-2019. Journal of Environmental Management 286: 112189. DOI: https:// doi.org/10.1016/j.jenvman.2021.112189.

Davidson, D.W., Arias, J.A. and Mann, J. (2006). An experimental study of bamboo ants in western Amazonia. Insect Society 53(1): 108 - 114. DOI: https:// doi.org/10.1007/s00040-005-0843-8.

Dida, J.J.V., Araza, A.B., Eduarte, G.T., Umali, A.G.A., Malabrigo Jr, P.L. and Razal, R.A. (2021). Towards nationwide mapping of bamboo resources in the Philippines: testing the pixel-based and fractional cover approaches, International Journal of Remote Sensing 42(9): 3380 - 3404. DOI: https://doi.org/10.1080/0143 1161.2020.1871099.

Didham, R.K., Tylianakis, J.M., Gemmell, N.J., Rand, T.A. and Ewers, R.M. (2007). Interactive effects of habitat modification and species invasion on native species decline. Trends in Ecology and Evolution 22(9): 489496. DOI: https://doi.org/10.1016/j.tree.2007.07.001.

Dutta, K. and Reddy, C.S. (2016). Geospatial analysis of reed bamboo (Ochlandra travancorica) invasion in Western Ghats, India. Journal of Indian Society of Remote Sensing 44: 699 - 711. DOI: https://doi. org/10.1007/s12524-015-0534-5.

Facelli, J.M. and Pickett, S.T.A. (1991). Plant litter: its dynamics and effects on plant community structure. Botanical Review 57(1): 2 - 31. DOI: https://doi. org/10.1007/BF02858763.

Fadrique, B., Veldman, J.W., Dalling, J.W., Clark, L.G., Montti, L., Ruiz-Sanchez, E., Rother, D.C., Ely, F., Farfan-Ríos, W., Gagnon, P. and Prada, C.M. (2020). Guidelines for including bamboos in tropical ecosystem monitoring. Biotropica 52(3): 427 - 443. DOI: https:// doi.org/10.1111/btp.12737.

Fadrique, B., Gann, D., Nelson, B.W., Saaatchi, S. and Feeley, K.J. (2021). Bamboo phenology and life cycle drive seasonal and long-term functioning of Amazonian bamboo-dominated forests. Journal of Ecology 109(2): 860 - 876. DOI: https://doi.org/10.1111/13652745.13512 .

Fernandez-Going, B.M., Anacker, B.L. and Harrison, S. (2012). Temporal variability in California grasslands: soil type and species functional traits mediate response to precipitation. Ecology 93(9): 2104 - 2114. DOI: https://doi.org/10.1890/11-2003.1.

Ferreira, E., Kalliola, R. and Ruokolainen, K. (2020). Bamboo, climate change and forest use: a critical combination for southwestern Amazonian forests? Ambio 49: 1353 - 1363. DOI: https://doi.org/10.1007/ s13280-019-01299-3.

Franklin, J., Serra-Diaz, J.M., Syphard, A.D. and Regan, H.M. (2016). Global change and vegetation dynamics. Proceedings of the National Academy of Sciences 113(14): 3725 - 3734. DOI: https:// doi.10.1073/pnas.1519911113.

$\mathrm{Fu}$, M., Xiao, J. and Lou, Y. (2000). Cultivation and Utilization on Bamboo. China Forestry Publishing House, Beijing Pp. 34 - 39.

Fujimaki, R., Takeda, H. and Wiwatiwitaya, D. (2008). Fine root decomposition in tropical dry evergreen and dry deciduous forests in Thailand. Journal of Forest Research 13(6): 338 - 346. DOI: https://doi.10.1007/ s10310-008-0087-3.

Fukushima, K., Usui, N., Ogawa, R. and Tokuchi, N. (2015). Impacts of moso bamboo (Phyllostachys pubescens) invasion on dry matter and carbon and nitrogen stocks in a broad-leaved secondary forest located in Kyoto, western Japan. Plant Species Biology 30(2): 81 - 95. DOI: https://doi.org/10.1111/1442-1984.12066.

Galetti, M., Giacomini, H.C., Bueno, R.S., Bernardo, C.S.S., Marques, R.M., Bovendorp, R.S., Steffler, C.E., Rubim, P., Gobbo, S.K., Donatti, C.I., Begotti, R.A., Meirelles, F., Nobre, R.D., Chiarello, A.G. and Peres, C.A. (2009). Priority areas for the conservation of Atlantic Forest large mammals. Biological Conservation 142(6): 1229 - 1241. DOI: https://doi. org/10.1016/j.biocon.2009.01.023.

García-Guzmán, G. and Benítez, J. (2003). Effect of litter on the incidence of leaf-fungal pathogens and herbivory in seedlings of the tropical tree Nectandra ambigens. Journal of Tropical Ecology 19: 171 - 177. DOI: https:// doi.org/10.1017/S0266467403003195. 
Ghinkul, S.G. (1936). Mass blossoming of bamboo in the light of phasic development theory. Soviet Subtropics 10(26): 24 - 29.

Ghosh, A. and Joshi, P.K. (2014). A comparison of selected classification algorithms for mapping bamboo patches in lower Gangetic plains using very high resolution World View 2 imagery. International Journal of Applied Earth Observation and Geoinformation 26: 298 - 311. DOI: https://doi.org/10.1016/j.jag.2013.08.011

Giordano, C.V, Sa'nchez, R.A., Austin, A.T. and Austin, A.T. (2009). Gregarious bamboo flowering opens a window of opportunity for regeneration in a temperate forest of Patagonia. New Phytologist 181(4): 880 - 889. DOI: https://doi.org/10.1111/j.1469-8137.2008.02708.x

Giebelmann, U.C., Martins, K.G., Brandle, M., Schadler, M., Marques, R. and Brandl, R. (2013). Lack of homefield advantage in the decomposition of leaf litter in the Atlantic rainforest of Brazil. Applied Soil Ecology 49: 5-10. DOI: https://doi.org/10.1016/j.apsoil.2011.07.010

Goyal, A.K., Ghosh, P.K., Dubey, P.K. and Sen, A. (2012). Inventorying bamboo biodiversity of North Bengal: a case study. International Journal of Fundamental and Applied Sciences 1(1): 5 - 8.

Greig, C., Robertson, C. and Lacerda, A.E.B. (2018). Spectral-temporal modelling of bamboo-dominated forest succession in the Atlantic Forest of Southern Brazil. Ecological Modeling 384(2018): 316 - 332. https://doi.org/10.1016/j.ecolmodel.2018.06.028.

Griscom, B.W. and Ashton, P.M.S. (2003). Bamboo control of forest succession: Guadua sarcocarpa in Southeastern Peru. Forest Ecology and Management 175(1-3): 445 - 454.

Griscom, B.W. and Ashton, P.M.S. (2006). A selfperpetuating bamboo disturbance cycle in a Neotropical forest. Journal of Tropical Ecology 22(5): 587 - 597. DOI: https://doi.org/10.1016/S0378-1127(02)00214-1.

Griscom, B.W. (2003). The Influence of Bamboo (Guadua sarcocarpa and Guadua weberbaueri) on Stand Dynamics in Lowland terra firme Forests of Southeastern Peru. PhD Dissertation. Yale University, New Haven, CT, USA.

Guilherme, F.A.G., Oliveira-Filho, A.T., Apollinário, V. and Bearzoti, E. (2004). Effects of flooding regime and woody bamboos on tree community dynamics in a section of tropical semideciduous forest in SouthEastern Brazil. Plant Ecology 174: 19 - 36. DOI: https:// doi:10.1023/B:VEGE.0000046051.97752.cd.

Harner, M.J., Crenshaw, C.L., Abelho, M., Stursova, M., Shah, J.J.F. and Sinsabaugh, R.L. (2009). Decomposition of leaf litter from a native tree and an Actinorhizal invasive across riparian habitats. Ecological Applications 19(5): 1135 - 1146.

Harrison, S., Davies, K.F., Safford, H.D. and Viers, J.H. (2006). Beta diversity and the scale-dependence of the productivity-diversity relationship: a test in the Californian serpentine flora. Journal of Ecology 94: 110 - 117. DOI: https://doi.org/10.1111/j.13652745.2005.01078.x.

Holl, K.D. (1999). Factors limiting tropical rain forest regeneration in abandoned pasture: seed rain, seed germination, microclimate, and soil. Biotropica 31: 229 - 242. DOI: https:// doi.org/10.1111/j.1744-7429.1999. tb00135.x.

IPCC Climate Change (2007). In: M.L. Parry, O.F. Canziani, J.P. Palutikofvan, P.J. der Linden and C.E. Hanson (Eds.), Impacts, Adaptation and Vulnerability, Cambridge University Press.

Isagi, Y. and Torii, A. (1997). Range expansion and its mechanisms in a naturalized bamboo species, Phyllostachys pubescens, in Japan. Journal of Sustainable Forestry 6(1-2): 127 - 141. DOI: https:// doi.org/10.1300/J091v06n01_08.

Jacobs, J., von May, R., Kavanaugh, D. and Connor, E. (2018). Beetles in bamboo forests: Community structure in a heterogeneous landscape of southwestern Amazonia. PeerJ 6. E5153. DOI: https://doi. org/10.7717/peerj.5153.

Jayawickrama, T., Karunaratne, I., Wijesundara, S. and Madawala, S. (2020). Community perceptions and responses on bamboo spread in native forests: a case study from Sri Lanka. International Journal of Sustainable Development and World Ecology 27(3): 240 - 249. DOI: https://doi.org/10.1080/13504509.201 9.1706057.

Jayawickrama, T., Karunaratne, I., Wijesundara, S. and Madawala, S. (2020). Bambusa bambos (L.) Voss. alters Structure and composition of native forests: a study from moist evergreen forests in Sri Lanka. Ceylon Journal of Science 49(2): 173 - 184. DOI: http://doi. org/10.4038/cjs.v49i2.7738.

Jose, C.M., Torres, L.M.B., Torres, M.A.M.G., Shirasuna, R.T., Farias, D.A., dos Santos, N.A. and Grombone-Guaratini, M.T. (2016). Phytotoxic effects of phenolic acids from Merostachys riedeliana, a native and overabundant Brazilian bamboo. Chemoecology 26(6): 235 - 246. DOI: https:// doi.org/10.1007/s00049-016-0224-y.

Keeley, J.E. and Bond, W.J. (1999). Mast flowering and semelparity in bamboos: the bamboo fire cycle hypothesis. The American Naturalist 154(3): 383 - 391.

Kelchner, S.A. and Group, B.P. (2013). Higher level phylogenetic relationships within the bamboos (Poaceae: Bambusoideae) based on five plastid markers. Molecular Phylogenetics and Evolution 67(2): 404 413. DOI: https://doi.org/10.1016/j.ympev.2013.02.005 Kigomo, B.N. (1988). Distribution, Cultivation and Research Status of Bamboo in Eastern Africa. Ecological Series Monograph No. 1. Nairobi, Kenya Forest Research Institute (KEFRI).

Kitzberger, T, Chaneton, E.J. and Caccia, F. (2007). Indirect effects of prey swamping: differential seed predation during a bamboo masting event. Ecology 88(10): 2541 - 2554. DOI: https://doi.org/10.1890/06-1587.1.

Kudo, G., Amagai, Y., Hoshino, B. and Kaneko, M. (2011). Invasion of dwarf bamboo into alpine snow-meadows in northern Japan: pattern of expansion and impact on species diversity. Ecology and Evolution 1(1): 85 - 96. DOI: https://doi.org/10.1002/ece3.9.

Kudo, G., Kawai, Y., Amagai, Y. and Winkler, D.E. (2017). Degradation and recovery of an alpine plant community: experimental removal of an encroaching 
dwarf bamboo. Alpine Botany 127(1): 75 - 83. DOI: https://doi.org/10.1007/s00035-016-0178-2.

Kudo, G., Aoshima, Y., Miyata, R. and Winkler, E. (2018). Altered morphologies and physiological compensation in a rapidly expanding dwarf bamboo in alpine ecosystems. Arctic, Antarctic, and Alpine Research 50: 1. DOI: https://doi.10.1080/15230430.2018.1463733.

Kurokawa, H., Peltzer, D.A. and Wardle, D.A. (2010). Plant traits, leaf palatability and litter decomposability for co-occurring woody species differing in invasion status and nitrogen fixation ability. Functional Ecology 24(3): 513 - 523.

Lacerda, A.E.B. and Kellermann, B. (2019). What is the long-term effect of bamboo dominance on adult trees in the Araucaria forest? a comparative analysis between two successional stages in Southern Brazil. Diversity 11(9): 165. DOI: https://doi.org/10.3390/ d11090165.

Larpkern, P., Moe, S.R. and Totland, S.R. (2011). Bamboo dominance reduces tree regeneration in a disturbed tropical forest. Oecologia 165: 161 - 168. DOI: https;// doi.161-8. 10.1007/s00442-010-1707-0.

Laurance, W.F., Delamonica, P., Laurance, S.G., Vasconcelos, H.L. and Lovejoy, T.E. (2000). Rainforest fragmentation kills big trees. Nature 4(6780): 836. DOI: http://dx.doi.org/10.1038/35009032.

Lenoir, J. and Svenning, J.C. (2015). Climate-related range shifts - towards a comprehensive research framework. Ecography 38(1): 15 - 28. DOI: https://doi.org/10.1111/ ecog.00967.

Lewis, S.L., Phillips, O.L., Baker, T.R., Lloyd, J., Malhi, Y., Almeida, S., Higuchi, N., Laurance, W.F., Neill, D.A., Silva, J.N.M., Terborgh, J., Torres Lezama, A., Vasquez Martinez, R., Brown, S., Chave, J., Kuebler, C., Nunez Vargas, P. and Vinceti, B. (2004). Concerted changes in tropical forest structure and dynamics: evidence from 50 South American long-term plots. Philosophical Transactions of the Royal Society London Series B 359(1443): 421 - 36. DOI: https://doi.org/10.1098/ rstb.2003.1431.

Li, Z.C., Fu, M.Y., Xie, J.Z., Li, R.G. and Xiao, J.H. (2003). Study on the productivity maintenance of bamboo and broad-leave tree mixed stands. Journal of Bamboo Research 22(1): 32-37.

Lima, R.A.F., Rother, D.C., Muler, A.E., Lepsch, I.F. and Rodrigues, R.R. (2012). Bamboo over abundance alters forest structure and dynamics in the Atlantic Forest hotspot. Biodiversity Conservation 147(1): 32 - 39. DOI: https://doi.org/10.1016/j.biocon.2012.01.015.

Linderman, M., Liu, J., Qi, J., An, L., Ouyang, Z., Yang, J., and Tan, Y. (2004). Using artificial neural networks to map the spatial distribution of understorey bamboo from remote sensing data. International Journal of Remote Sensing 25(9): 1685 - 1700. DOI: https://doi.or $\mathrm{g} / 10.1080 / 01431160310001598971$.

Liu, W., Liao, L., Liu, Y., Wang, Q., Murray, P., Jiang, X., Zou, G., Cai, J. and Zhao, X. (2021). Effects of Phyllostachys pubescens expansion on underground soil fauna community and soil food web in a Cryptomeria japonica plantation, Lushan Mountain, subtropical China. Journal of Soils and Sediments. 21(6): 2212 - 2227.
DOI: https://doi.org/10.1007/s11368-021-02923-0.

Liu, W., Fox, J.E.D. and Xu, Z. (2000). Leaf litter decomposition of canopy trees, bamboo and moss in a montane moist evergreen broad-leaved forest +on Ailao Mountain, Yunnan, south-west China. Ecological Research 15(4): 435 - 447.

Liao, C., Peng, R., Luo, Y., Zhou, X., Wu, X., Fang, C., Chen, J. and Li, B. (2008). Altered ecosystem carbon and nitrogen cycles by plant invasion: a metaanalysis. New Phytologist 77(3): 706 - 714. https://doi. org/10.1111/j.1469-8137.2007.02290.x.

Lobovikov, M., Ball, L., Guardia, M. and Russo, L. (2007). World bamboo resources: a thematic study prepared in the framework of the global forest resources assessment (2005) (No. 18). Food and Agriculture Organization. Pp 11.

Lou, Y., Li, Y., Buckingham, K., Henley, G. and Guomo, Z. (2010). Bamboo and climate change mitigation. Technical Report No. 32. International Network for Bamboo and Rattan (INBAR) P. O. Box 100102-86, Beijing 100102, China.

Mack, R.N., Simberloff, D., Lonsdale, W.M. Evans, H., Clout, M. and Bazzaz, F.A. (2000). Biotic invasions: causes, epidemiology, global consequences, and control. Ecological Applications 10(3): 689 - 710. https://doi.org/10.1890/1051-0761(2000)010[0689:BI CEGC]2.0.CO;2.

Madawala, H.M.S.P. (2014). Austroeupatorium inulifolium invasion increase arbuscular mycorrhizal abundance in Cymbopogon-dominated grasslands in Knuckles Conservation Area. Journal of National Science Foundation 42(4): 405 - 408. DOI: http://dx.doi. org/10.4038/jnsfsr.v42i4.7735.

Mafaziya, F., Wijewickrama, T. and Madawala, H.M.S.P. (2019). Does over-dominance of Bambusa bambos (L.) Voss. alter abundance and richness of arbuscular mycorrhizal fungal community in forests? Ceylon Journal of Science 48(1): 51 - 59. DOI: http://doi. org/10.4038/cjs.v48i1.7588.

Marchesini, V.A., Sala, O.E. and Austin, A.T. (2009). Ecological consequences of a massive flowering event of bamboo (Chusquea culeou) in a temperate forest of Patagonia, Argentina. Journal of Vegetation Science 20: 424 - 432. DOI: https://doi.org/10.1111/j.16541103.2009.05768.x.

Masaki, T., Tanaka, N., Yagihashi, T., Ogawa, M., Tanaka,H., Sugita, H., Sato, T. and Nagaike, T. (2021). Dynamics of dwarf bamboo populations and tree regeneration over 40 years in a clear-cut beech forest: effects of advance weeding and herbicide application, Journal of Forest Research 26(1): 43 - 53. DOI: https://doi.org/10 $.1080 / 13416979.2020 .1847376$.

McKinney, M.L. and Lockwood, J.L. (1999). Biotic homogenization: a few winners replacing many losers in the next mass extinction. Trends in Ecology \& Evolution 14(11): 450 - 453. DOI: https://doi.org/10.1016/S01695347(99)01679-1.

Medeiros, H., Castro, W., Salimon, C.I., Brasil da Silva, I. and Silveira, M. (2013). Tree mortality, recruitment and growth in a bamboo dominated forest fragment in southwestern Amazonia, Brazil. Biota Neotropica 
13(2): 29-34. DOI: https://doi.org/10.1590/S167606032013000200002 .

Millangoda, U. and Madawala, S. (2018). Does overabundance of Bambusa bambos (L.) Voss. Alter edaphic properties? Ceylon Journal of Science 47(3): 281 - 286. DOI: http://doi.org/10.4038/cjs.v47i3.7535.

Moldenke, A., Pajutee, M. and Ingham, E. (2000). The functional roles of forest soil arthropods: the soil is a lively place. Proceedings of the California Forest Soils Council Conference on Forest Soils Biology and Forest Management. USDA Forest Service, Pacific Southwest Research Station, Gen Tech Rep PSW-GTR-178, Berkeley, California, USA. Pp. 7 - 22.

Montti, L., Villagra, M., Campanello, P.I., Gatti, M.G. and Goldstein, G. (2014). Functional traits enhance invasiveness of bamboos over co-occurring tree saplings in the semi deciduous Atlantic Forest. Acta Oecologia 54: 36 - 44. DOI: https://doi.org/10.1016/j. actao.2013.03.004.

Montti, L., Campanello, P.I., Gatti, M., Genoveva, Blundo, C., Austin, A.T., Sala, O.E. and Goldstein, G. (2011). Understory bamboo flowering provides a very narrow light window of opportunity for canopy-tree recruitment in a neotropical forest of Misiones, Argentina. Forest Ecology and Management 262(8): 1360 - 1369. DOI: https://doi.org/10.1016/j.foreco.2011.06.029.

Nascimento, H.E.M. and Laurance, W.F. (2004). Biomass dynamics in Amazonian forest fragments. Ecological Applications 14(sp4): 127 - 138. DOI: https://doi. org/10.1890/01-6003.

Okutomi, K., Shinoda, S. and Fukuda, H. (1996). Causal analysis of the invasion of broadleaved forest by bamboo in Japan. Journal of Vegetation Science 7: 723 - 728. DOI: https://doi.10.2307/3236383.

Oliveira-Filho, A.T., Vilela, E.A., Gavilanes, M.L. and Carvalho, D.A. (1994). Effect of flooding regime and understorey bamboos on the physiognomy and tree species composition of a tropical semi deciduous forest in southeastern Brazil. Vegetatio 113: 99 - 124. DOI: https://doi.org/10.1007/BF00044229.

Pagad, S. (2016). Bamboos and invasiveness- identifying which bamboo species pose a risk to the natural environment and what can be done to reduce this risk. INBAR Working Paper No.77. International Network for Bamboo and Rattan, Beijing, China.

Parmesan, C. and Yohe, G. (2003) A globally coherent fingerprint of climate change impacts across natural systems. Nature 421: 37 - 42. DOI: https://doi. org/10.1038/nature01286.

Parmesan, C. (2006). Ecological and evolutionary responses to recent climate change. Annual Review of Ecology, Evolution and Systematics 37(1): 637-669. DOI: https:// doi.org/10.1146/annurev.ecolsys.37.091305.110100.

Parsons, S. and Congdon, R. (2008). Plant litter decomposition and nutrient cycling in north Queensland tropical rain-forest communities of differing successional status. Journal of Tropical Ecology 24: 317 - 327. DOI: https://doi.org/10.1017/ S0266467408004963.
Pivello, V.R., Vieira, M.V., Grombone-Guaratini, M.T. and Matos, D.M.S. (2018). Thinking about super-dominant populations of native species - Examples from Brazil. Perspectives in Ecology and Conservation 16(2): 74 82. DOI: https://doi.org/10.1016/j.pecon.2018.04.001.

Piyasinghe, I.P.K., Gunatilake, J. and Madawala, H.M.S.P. (2019). Austroeupatorium inulifolium invasion alters litter dynamics in Cymbopogon nardus-dominated man-made grasslands. Journal of the National Science Foundation of Sri Lanka 47(1): 39 - 49. DOI: http:// dx.doi.org/10.4038/jnsfsr.v47i1.8926.

Prematilleke, K. and Madawala, S. (2008). A case study: The effect of invasive shrub (Ochlandra stridula) on the structure and diversity in the Meethirigala Forest Reserve, Sri Lanka. Proceedings of the National Symposium of Alien Invasive species, Colombo, Sri Lanka. Pp. 69-76.

Prematilleke, K.P., Madawala, S. and Weerawardene, N.D.R. (2015). Biodiversity survey on Meethirigala forest reserve with special reference to the invasion of Ochlandra stridula. The Sri Lanka Forester 36 - 37: 25 -40 .

Ramanayake, S.M.S.D., Meemaduma, V.N. and Weerawardene, T.E. (2007). Genetic diversity and relationships between nine species of bamboo in Sri Lanka, using random amplified polymorphic DNA. Plant Systematics and Evolution 269(1 - 2): 55 - 61.

Rao, A.N., Rao, V.R. and Williams, J.T. (1998). (Eds), Priority Species of Bamboo and Rattan. Serdang, IPGRI-APO.

Reid, S., Díaz, I., Armesto, J.J. and Willson, Mary. (2004). Importance of native bamboo for understory birds in Chilean temperate forests. The Auk 121(2): 515-525. DOI: https://doi.10.1642/00048038(2004)121[0515:IONBFU]2.0.CO;2.

Rockwell, C.A., Kainer, K.A., d'Oliveira, M.V.N., Staudhammer, C.L. and Baraloto, C. (2014). Logging in bamboo-dominated forests in southwestern Amazonia: caveats and opportunities for smallholder forest management. Forest Ecology and Management 315: 202 - 210. DOI: https://doi.org/10.1016/j. foreco.2013.12.022.

Rother, D.C., Rodrigues, R.R. and Pizo, M.A.(2009). Effects of bamboo stands on seed rain and seed limitation in a rainforest. Forest Ecology and Management 257: 885 - 892. DOI: https://doi:10.1016/j.foreco.2008.10.022.

Rother, D.C., Alves, K.J.F. and Pizo, M.A. (2013). Avian assemblages in bamboo and non-bamboo habitats in a tropical rainforest. Emu 113: 52 - 61. DOI: https:// doi:10.1071/MU12017.

Rother, D.C., Rodrigues, R.R. and Pizo, M.A. (2016). Bamboo tickets alter the structure of Euterpe edulis population: a threatened palm of the Atlantic forest. Acta Oecologica 70: 96 - 102. DOI: https://doi:10.1016/j. actao.2015.11.008.

Rother, D.C., Gorgens, E., Guerin, N., Rodrigues, R.R. and Pizo, M.A. (2018). Seedling community in a patchy topical vegetation under the influence of bamboos. Tropical Conservation Science 11: 1 - 10. DOI: https:// doi.10.1177/1940082918767124. 
Roy, A., Bhattacharya, S., Ramprakash, M., Kumar, S.A. (2016). Modelling critical patches of connectivity for invasive Maling bamboo (Yushania maling) in Darjeeling Himalayas using graph theoretic approach. Ecological Modelling 329: 77- 85. DOI: https://doi. org/10.1016/j.ecolmodel.2016.02.016.

Schnitzer, S.A. and Bongers, F. (2002). The ecology of lianas and their role in forest. Trends in Ecology and Evolution 17(5): 223 - 230. DOI: https://doi. org/10.1016/S0169-5347(02)02491-6.

Schnitzer, S.A. and Bongers, F. (2011). Increasing liana abundance and biomass in tropical forests: emerging patterns and putative mechanisms. Ecological Letters 14(4): 397 - 406. DOI: https://doi.org/10.1111/j.14610248.2011.01590.x.

Schnitzer, S.A. and Carson, W.P. (2010). Lianas suppress tree regeneration and diversity in treefall gaps. Ecological Letters 13(7): 849 - 857. DOI: https://doi. org/10.1111/j.1461-0248.2010.01480.x.

Schweizer, D., Rother, D. Muler, A., Rodrigues, R., Pizo, M. and Brancalion, P. (2017). Effects of bamboo dominance and palm-heart harvesting on the phylogenetic structure of the seed and seedling communities in an old-growth Atlantic Forest. Journal of Tropical Ecology 33(5): 309 - 316. DOI: https://doi. org/10.1017/S0266467417000281.

Sharma, M.L. and Nirmala, C. (2015). Bamboo Diversity of India: An update. 10 $0^{\text {th }}$ World Bamboo Congress, Korea, 2015.

Sharma, G.P. and Raghubanshi, A. (2009). Lantana invasion alters soil nitrogen pools and processes in the tropical dry deciduous forest of India. Applied Soil Ecology 42(2): 134 - 140. DOI: https://doi.org/10.1016/j. apsoil.2009.03.002.

Sheil, D. (2016). Disturbance and distributions: avoiding exclusion in a warming world. Ecology and Society 21(1): 10. DOI: http://dx.doi.org/10.5751/ES-07920210110.

Shen, Q.L. (2015). Characteristics and evolution of ammonia-oxidizing and nitrogen-fixing bacteria in moso bamboo (Phyllostachys Pubescens) forest soils. Ph.D. Dissertation, Zhejiang A\&F University.

Shiau, Y.J. and Chiu, C.Y. (2017). Changes in soil biochemical properties in a Cedar plantation invaded by moso bamboo. Forests 8: 222. DOI: https://doi. org/10.3390/f8070222.

Shinohara, Y. and Otsuki, K. (2015). Comparisons of soilwater content between a moso bamboo (Phyllostachys pubescens) forest and an evergreen broadleaved forest in western Japan. Plant Species Biology 30(2): 96-103. DOI: https:/doi.10.1111/1442-1984.12076.

Simberloff, D., Souza, L., Nũnez, M.A., Barrios-Garcia, N.M. and Bunn, W. (2012). The natives are restless, but not often and mostly when disturbed. Ecology 93(3): 598 - 607. DOI: https://doi.org/10.1890/11-1232.1

Smith, M. and Nelson, B.W. (2011). Fire favours expansion of bamboo-dominated forests in the south-west Amazon. Journal of Tropical Ecology 27(1): 59 - 64. DOI: https://doi.org/10.1017/S026646741000057X.

Soderstrom, T.R. and Ellis, R.P. (1988). The woody bamboos (Poaceae: Bambuseae) of Sri Lanka: a morphological- anatomical study. Smithsonian Contributions to Botany 72: 1 - 75.

Song, Q.N., Lu, H., Liu, J., Yang, J., Yang, G.Y. and Yang, Q.P. (2017). Accessing the impacts of bamboo expansion on NPP and N cycling in evergreen broadleaved forest in subtropical China. Science Reports 7(1): 40383. DOI: https://doi.org/10.1038/srep40383.

Song, Q.N., Ouyang, M., Yang, Q.P., Lu, H., Yang, G.Y., Chen, F.S. and Shi, J.M. (2016). Degradation of litter quality and decline of soil nitrogen mineralization after moso bamboo (Phyllostachys pubscens) expansion to neighboring broadleaved forest in subtropical China. Plant Soil 404(1): 113-124. DOI: https://doi. org/10.1007/s11104-016-2835-Z.

Song, X., Zhou, G., Gu, H. and Qi, L. (2015). Management practices amplify the effects of $\mathrm{N}$ deposition on leaf litter decomposition of the Moso bamboo forest. Plant Soil 395: 391 - 400. DOI: https://doi.org/10.1007/ s11104-015-2578-2.

Soreng, R., Peterson, P., Romaschenko, K., Davidse, G., Teisher, J., Clark, L., Barberá, P., Gillespie, L. and Zuloaga, F. (2017). A worldwide phylogenetic classification of the Poaceae (Gramineae) II: An update and a comparison of two 2015 classifications: Phylogenetic classification of the grasses II. Journal of Systematics and Evolution 55: 259 - 290. DOI: https:// doi.org/10.1111/jse.12262.

Srivastava, V., Griess, V.C. and Padalia, H. (2018). Mapping invasion potential using ensemble modelling. A case study on Yushania maling in the Darjeeling Himalayas. Ecological Modelling 385: 35 - 44. DOI: https://doi. org/10.1016/j.ecolmodel.2018.07.001

Stefanowicz, A., Stanek, M., Majewska, M., Nobis, M. and Zubek, S. (2019). Invasive plant species identity affects soil microbial communities in a mesocosm experiment. Applied Soil Ecology 136: 168 - 177. DOI: https://doi. org/10.1016/j.apsoil.2019.01.004

Stohlgren, T.J., Barnett, T.D., Jarnevich, C.S., Flather, C. and Kartesz, J. (2008). The myth of plant species saturation. Ecology Letters 11: 313 - 326. DOI: 10.1111/j.1461-0248.2008.01153.x.

Suzuki, S. (2015). Chronological location analyses of giant bamboo (Phyllostachys pubescens) groves and their invasive expansion in a satoyama landscape area, western Japan. Plant Species Biology, 30(1), 63-71. DOI: https://doi.org/10.1111/1442-1984.12067

Swaine, M.D. and Grace, J. (2007). Lianas may be favored by low rainfall: evidence from Ghana. Plant Ecology 192(2): 271 - 276. DOI: https://doi. org/10.1007/s11258-007-9319-4

Swaine, M.D. and Whitmore, T.C. (1988). On the definition of ecological species groups in tropical rain forests. Vegetatio 75(1 - 2): 81 - 86.Available at DOI: https:// doi.org/10.1007 /BF00044629. Accessed on the $15^{\text {th }}$ September, 2020.

Talley, T.S., Nguyen, K.C. and Nguyen. A. (2012). Testing the effects of an introduced palm on a riparian invertebrate community in southern California. PLOS ONE 7(8). Available from: DOI: https://doi. org/10.1371/journal.pone.0042460. Accessed on the $16^{\text {th }}$ September, 2020. 
Tang, J., Körner, C., Muraoka, H., Piao, S., Shen, M., Thackeray, S.J. and Yang, X. (2016). Emerging opportunities and challenges in phenology: a review. Ecosphere 7(8): DOI: https://doi.org/10.1002/ecs2. 1436.

Taylor, A.H., Reid, D.G., Qin, Z. and Hu, J. (1991). Spatial patterns and environmental associates of bamboo (Bashania fangiana Yi) after mass-flowering in southwestern China. Bull. Torrey Bot. Club 118: 247 254. DOI: https://doi.org/10.2307/2996639.

Tian, X.K., Wang, M.Y., Meng, P., Zhang, J.S., Zhou, B.Z., Ge, X.G., Yu, F.H. and Li, M.H. (2020). Native bamboo invasions into subtropical forests alter microbial communities in litter and soil. Forests 11: 314. DOI: https://doi.org/10.3390/f11030314.

Tomimatsu, H., Yamagishi, H., Tanaka, I., Sato, M., Kondo, R., and Konno, Y. (2011). Consequences of forest fragmentation in an understory plant community: extensive range expansion of native dwarf bamboo. Plant Species Biology 26: 3 - 12. DOI: https://doi. org/10.1111/j.1442-1984.2010.00310.x.

Tripathi, S.K., Sumida, A., Shibata, H., Ono, K., Uemura, S., Kodama, Y. and Hara, T. (2006). Leaf litterfall and decomposition of different above- and below-ground parts of birch (Betula ermanii) trees and dwarf bamboo (Sasa kurilensis) shrubs in a young secondary forest in Northern Japan. Biology and Fertility of Soils 43(2): 237 - 246. DOI: https://doi.org/10.1007/s00374-006$0100-\mathrm{y}$.

Tu, L.H., Hu, H.L., Chen, G., Peng, Y., Xiao, Y.L., Hu, T.X., Zhang, J., Li, X., Liu, L. and Tang, Y. (2014). Nitrogen addition significantly affects forest litter decomposition under high levels of ambient nitrogen deposition. PLoS One 9: e88752. DOI: https://doi.org/10.1371/journal. pone. 0088752 .

Tuanmu, M.N., Viña, A., Winkler, J.A., li, Y., Xu, W., Ouyang, Z. and Liu, J. (2013). Climate-change impacts on understorey bamboo species and giant pandas in China's Qinling Mountains. Nature Climate Change 3(3): 249 - 253. DOI: https://doi.org/10.1038/ nclimate 1727.

Uchimura, E. (1987). Growth environmental and characteristics of some tropical bamboos. Bamboo Journal 4: 51 - 60.

Umemura, M. and Takenaka, C. (2014). Changes in chemical characteristics of surface soils in hinoki cypress (Chamaecyparis obtusa) forests induced by the invasion of exotic Moso bamboo (Phyllostachys pubescens) in central Japan. Plant Species Biology 30(1): 72 - 79. DOI: https://doi.org/10.1111/14421984.12038.

Valéry, L., Fritz, H. and Lefeuvre, J.C. (2013). Another call for the end of invasion biology. Oikos 122(8): 1143-1146. DOI: https://doi.org/10.1111/j.16000706.2013.00445.x.

Vandvik, V., Klanderud, K., Meineri, E., Måren, I. and Töpper, J. (2016). Seed banks are biodiversity reservoirs: Species-area relationships above versus below ground. Oikos 125: 218 - 228. DOI: https://doi. org/10.1111/oik.02022.
Veldman, J.W. and Putz, F.E. (2011). Grass-dominated vegetation, not species-diverse natural savanna, replaces degraded tropical forests on the southern edge of the Amazon Basin. Biological Conservation 144(5): 1419 - 1429. DOI: https://doi.org/10.1016/j. biocon.2011.01.011.

Wang, C., Zhou, J., Liu, J., Jiang, K., Xiao, H. and Du, D. (2017). Responses of the soil fungal communities to the co-invasion of two invasive species with different cover classes. Plant Boilogy 20(1): 151 - 159. DOI: https://doi.org/10.1111/plb.12646.

Wang, T., Skidmore, A.K. and Toxopeus, A.G. (2009). Improved understorey bamboo cover mapping using a novel hybrid neural network and expert system. International journal of remote sensing 30(4): 965 - 981. DOI: https://doi. org/10.1080/01431160802411867.

Watling, J.I., Hickman, C.R. and Orrock, J.L. (2011). Predators and invasive plants affect performance of amphibian larvae. Oikos 120: 735 - 739. DOI: https:// doi.org/10.1111/j.1600-0706.2010.19255.x.

Wijewickrama, T., Karunaratne, I., Wijesundara, S. and Madawala, S. (2019). Community perceptions and responses on bamboo spread in native forests: a case study from Sri Lanka, International Journal of Sustainable Development and World Ecology 27(3): 240-249. DOI: https://doi.10.1080/13504509.2019.17 06057.

Wijewickrama, M.P.T., Karunaratne, W.A.I.P., Wijesundara, D.S.A. and Madawala, H.M.S.P. (2020). Bambusa bambos (L.) Voss. alters Structure and composition of native forests: a study from moist evergreen forests in Sri Lanka, Ceylon Journal of Science 49(2): 173 - 184. DOI: http://doi.org/10.4038/cjs.v49i2.7738.

Wijewickrama, M.P.T. (2020). Investigation on Ecological and Socio-Economic Impacts of Bambusa bambos (L.) Voss.in Intermediate Zone forests in Sri Lanka. PhD Dissertation, Postgraduate Institute of Science, University of Peradeniya.

Wijewickrama, T., Karunaratne, I., Wijesundara, S. and Madawala, S. (2021). Impacts of Bambusa bambos spread on seedling recruitment, mortality and regeneration potential of native species in tropical moist evergreen forests of Sri Lanka. Journal of Tropical Forest Science (In press).

Winkler, D.E., Amagai, Y., Huxman, T.E., Kaneko, M. and Kudo, G. (2016). Seasonal dry-down rates and high stress tolerance promote bamboo invasion above and below treeline. Plant Ecology 217(10): 1219-1234. DOI: https://doi.org/10.1007/s11258-016-0649-y.

Wolkovich, E.M., Bolger, D.T. and Holway, D.A. (2009). Complex responses to invasive grass litter by ground arthropods in a Mediterranean scrub ecosystem. Oecologia 161(4): 697 - 708. DOI: https://doi. org/10.1007/s00442-009-1425-7.

Wu, J. S., Jiang, P. K., and Wang, Z. L. (2008). The effects of Phyllostachys pubescens expansion on soil fertility in National Nature Reserve of Mount Tianmu. Acta Agriculturae Universitatis Jiangxiensis, 30(4), 689692. 
Xiao, F.M., Fan, S.H., Wang, S.L., Xiong, C.Y., Zhang, C., Liu, S.P. and Zhang, J. (2007). Carbon storage and spatial distribution of Phyllostachys pubescens and Cunninghamia lanceolata plantation ecosystem. Acta Phytoecologica Sinica 27(4): 2794 - 2801.

Xiao J. (2000). Review and prospect of bamboo industry development in China. Journal of Bamboo Research 19(1): 1 - 5 .

Xie, H.H., Su, A.L., Wu, C.Z., Lin, Y.M., Hong, W., Li, J., Chen, C. and Hong, T. (2014). Carbon density of Phyllostachys edulis plantation ecosystem in typical growth area of Fujian Province. Journal of Southwest Forestry University 34(2): 28 - 34.

Xu, Q., Jiang, P.-K., Wu, J.S., Zhou, G.M., Shen, R.F. and Fuhrmann, J.J. (2014). Bamboo invasion of native broadleaf forest modified soil microbial communities and diversity. Biological Invasions 17(1): 433 - 444. DOI: https://doi.org/10.1007/s10530-014-0741-y.

Xu, Q.F., Liang, C.F., Chen, J.H., Li, Y.C., Qin, H. and Fuhrmann, J.J. (2020). Rapid bamboo invasion (expansion) and its effects on biodiversity and soil processes. Global Ecology and Conservation. 21: e00787. DOI: https://doi.org/10.1016/j.gecco.2019. e00787.

Xu, X., Hui, D., King, A.W., Song, X., Thornton, P.E. and Zhang, L. (2015). Convergence of microbial assimilations of soil carbon, nitrogen, phosphorus and sulfur in terrestrial ecosystems. Scientific Reports 5(1): 1-8. DOI: https://doi.org/10.1038/srep17445.

Yang, S.Z., Du, Q.Z., Chen, J.X. and Liu, L. (2008). Effect of Phyllostachys heterocycla var. pubescens spreading on bird diversity. Journal of Zhejiang Forest Science and Technology 28: 43 - 46.

Yang, S.J., Sun, M., Zhang, Y.J., Cochard, H. and Cao, K.F. (2014). Strong leaf morphological, anatomical, and physiological responses of a subtropical woody bamboo (Sinarundinaria nitida) to contrasting light environments. Plant Ecology 215(1): 97 - 109. DOI: https://doi.org/10.1007/s11258-013-0281-z.
Yang, Q.P., Yang, G.Y., Song, Q.N., Shi, J.M., Ouyang, M., Qi, H.Y. and Fang, X.M. (2015). Ecological studies on bamboo expansion: process, consequence and mechanism. Chinese Journal of Plant Ecology 39(1): 110 - 124. DOI: https://doi:10.17521/ cjpe.2015.0012.

Yeasmin, L., Ali, M.N., Gantait, S. and Chakraborthy, S. (2015). Bamboo: an overview on its genetic diversity and characterization. 3 Biotech 5(1): 1 - 11. DOI: https://doi.org/10.1007/s13205-014-0201-5.

Ying, W., Jin, J., Jiang, H., Zhang, X., Lu, X., Chen, X. and Zhang, J. (2016). Satellite-based detection of bamboo expansion over the past 30 years in Mount Tianmushan, China. International Journal of Remote Sensing 37(13): 2908 - 2922. DOI: https://doi.org/10.1080/01431161.2 016.1186851.

Zhang, K., Cheng, X., Dang, H., Ye, C., Zhang, Y. and Zhang, Q. (2013). Linking litter production, quality and decomposition to vegetation succession following agricultural abandonment. Soil Biology and Biochemistry 57: 803 - 813. DOI: https://doi. org/10.1016/j.soilbio.2012.08.005.

Zhang, J., Li, H., Zhang, H., Zhang, H. and Tang, Z. (2021). Responses of litter decomposition and nutrient dynamics to nitrogen addition in temperate shrublands of North China. Frontiers in Plant Science 11: 2233. DOI: https://doi.org/10.3389/fpls.2020.618675.

Zhang, Y.X., Guo, C. and Li, D.Z. (2020). A new subtribal classification of Arundinarieae (Poaceae, Bambusoideae) with the description of a new genus. Plant Diversity 42: 127 - 134. DOI: https://doi. org/10.1016/j.pld.2020.03.004.

Zhou, B.Z., Fu, M., Xie, J.Z., Yang, X.S. and Li, Z.C. (2005). Ecological functions of bamboo forest: research and application. Journal of Forestry Research 16(2): 143 - 147.

Zuidema, P.A., Baker, P.J., Groenendijk, P., Schippers, P., van der Sleen, P., Vlam, M. and Sterck, F. (2013). Tropical forests and global change: filling knowledge gaps. Trends in Plant Science 18(8): 1360-1385. DOI: https://doi.org/10.1016/j.tplants.2013.05.006. 